\title{
Large-scale rock slope failures in the eastern Pyrenees: identifying a sparse but significant population in paraglacial and parafluvial contexts
}

\author{
David Jarman ${ }^{1}$, Marc Calvet ${ }^{2}$, J ordi Corominas ${ }^{3}$, Magali Delmas ${ }^{2}$, Yanni Gunnell ${ }^{4}$ \\ ${ }^{1}$ Mountain Landform Research, Scotland \\ 2 University of Perpignan, CNRS UMR 7194, France \\ ${ }^{3}$ Universitat Politècnica de Catalunya, Barcelona, Spain \\ ${ }^{4}$ University of Lyon, CNRS UMR 5600, France
}

\begin{abstract}
This first overview of large-scale rock slope failure (RSF) in the Pyrenees addresses the eastern third of the range. Around 30 principal RSFs $>0.25 \mathrm{~km}^{2}$ and 20 lesser or uncertain cases have been identified from remote imagery and groundtruthing. Compared with other European mountain ranges, RSF incidence is relatively sparse, displays no obvious regional trend or spatial clustering, and occurs across diverse landscape types, if mainly on metamorphic rocks. A transition is observed from paraglacial RSFs in formerly-glaciated valleys to what are here termed 'parafluvial' RSFs, within wholly or mainly fluvial valleys but where slope failure is not directly provoked by or linked to river erosion. RSFs are particularly found in three topographic settings: (i) at cirque and trough-head thresholds (transition zones of elevated instability between cirque and main glaciated trough walls); (ii) near the upper or outer periphery of the ice field, where glacial adaptation of fluvial valleys is incomplete; and (iii) in fluvial valleys beyond glacial limits where incision is locally intense. RSF is absent from the range divide, from within cirques, and from most main valleys. In the montane areas, RSF is strongly associated with vestiges of preglacial summit surfaces, confirming that plateau ridges are less stable than sharpened crests and horns. RSF is contributing significantly to the progressive destruction of this paleic relief. The overall sparsity of RSF indicates insufficient rock mass stresses, including rebound after concentrated bedrock erosion. This may reflect a relatively weak imprint of glacial erosion, including breaching, in a context of relatively low mean rates of neotectonic uplift, possibly signalling overall that eastern Pyrenees landscapes are close to dynamic equilibrium.
\end{abstract}

Key words: Pyrenees, rock slope failure, trough-head thresholds, paleic relief, paraglacial, parafluvial

\section{Introduction: RSF and its drivers in the mountains of Europe}

Rock slope failure (RSF) is an umbrella term embracing bedrock landslips, rockslides, and slope deformations. RSF is becoming recognised globally as a prime agent of erosion in mountain ranges, particularly where uplift rates are high and glacial or fluvial incision is deep - e.g. in the Himalaya (Burbank et al. 1996), Taiwan (Hovius et al. 2000), or the Southern Alps of New Zealand (Korup et al. 2007). In Europe, RSF has long been recognised in the Alps, initially as an active hazard (Heim 1932), and now, by systematic mapping, as pervasive in many massifs (Agliardi et al. 2013; Tonini et al. 2013). The largest rockslides 
such as Flims and Köfels exceed $1000 \mathrm{M} \mathrm{m}^{3}$ (von Poschinger 2002), as do some very large debris fans which may result from catastrophic events ( $\mathrm{J}$ arman et al. 2011). More subtle deep-seated gravitational slope deformations (DSGSD), formerly known as sackungen, are of kilometric extent and hectometric penetration, preparing valley walls for future rapid widening or collapse (Crosta and Zanchi 2000; Crosta et al. 2013). Overviews in the Caledonian mountain ranges have found abundant RSF, albeit amongst topographically similar areas of perplexing sparsity, in parts of the English Lake District (Wilson et al. 2004), the Scottish Highlands (J arman 2006) and Scandinavia (Bjerrum and J ørstad 1968; Jarman 2002, 2009). Until now there have been no regional overviews of RSF incidence in the Pyrenees.

\subsection{RSF drivers - rebound effects}

RSF requires both drivers and triggers. A key driver has conventionally been assumed to be the undercutting of slopes by glaciers and rivers, thus daylighting inclined bedding planes, faults, or major joint-sets; triggers have been variously identified as peak rainfall or meltwater saturation, high cleft-water pressures, debuttressing after ice retreat, seismic shaking, or simply progressive weakening. However, all these factors are more or less endemic, applying to all valleysides in relevant zones, whereas RSF incidence is often notably sporadic (J arman 2009; see also McColl 2012, who notably challenges the debuttressing notion). A more fundamental driver now gaining recognition concerns rebound stresses, which create or accentuate rock-mass instabilities, and may provoke ground ruptures. Rebound is usually seen as glacio-isostatic unloading (Gregersen and Basham 1989; Stewart et al. 2000), which will clearly vary both regionally (e.g. Ballantyne et al. 2014; Cossart et al. 2013), and between trough floor and rim. Rebound stresses due to bedrock erosion have been recognised in one RSF classification (Hutchinson 1988). However, where troughs are well adapted to ice discharge, bedrock erosion is typically very limited, often only an additional few metres per glacial cycle (Koppes and Montgomery 2009; Dühnforth, et al. 2010); this will only marginally augment rebound from ice unloading. Likewise, while fluvial incisions may be deep, the resulting mountain ravines involve little bulk erosion. All these rebound variants suffer in explanatory power from being endemic, along with the conventional explanations.

Only in special circumstances may bedrock erosion be sufficiently concentrated to generate additional rebound stresses capable of exceeding slope stability thresholds and provoking RSF (Jarman 2006; Ustaszewski et al. 2008) (cf. Mollard 1977; McColl 2012). Such situations might include new or enlarged glacial breaches and the troughs down-ice from them, where several hundred metres of incision may have occurred over recent glacial cycles (e.g. Glen Roy in Scotland: Jarman 2008). In fluvial contexts, concentrated erosion can occur in catchments subjected to capture or rapid uplift. RSF incidence may thus be a useful indicator of where localised disturbances to steady-state conditions are provoking pulsed landscape evolution.

\subsection{Paraglacial and parafluvial RSF: a Pyrenean test}

In heavily glaciated mountain ranges such as the Alps, most RSF is 'paraglacial' (sensu Ballantyne 2002), in that it is not directly a product of glaciation but would 
not have occurred without significant glacial erosion. However, RSF also occurs abundantly in the minimally-glaciated Apennines, and in adjacent glacial and fluvial contexts in the Carpathians; even in the Scottish Highlands, $\sim 5 \%$ of RSFs are in fluvial valleys or fluvially-modified glacial valleys. Indeed, RSF of slope deformation character was originally reported from the Hercynian mountains of Central Europe (Zischinsky 1966), where fluvial incision is predominant.

A further important distinction has to be made between directly 'fluvial RSFs' provoked by and connected to an eroding river, and RSFs on slopes in fluviallycut valleys but above the active influence of the river. The former tend to be small and numerous, the latter larger and less frequent, often resembling paraglacial RSFs. For the latter we propose the term 'parafluvial RSFs' - not directly a product of slope-foot undercutting by a river but within a valley or slope context wholly or predominantly attributable to fluvial processes. The terms paraglacial and parafluvial are not exactly complementary, as the former occurs temporally after a glacial process domain has ceased, while the latter occurs spatially segregated within a continuing fluvial process domain. Nor is this is a simple dichotomy, but rather a transition between decreasing glacial/increasing fluvial preconditioning (elaborated in 4.4 below). Since the introduction of new terms in geomorphology requires closer justification than space here allows, we discuss its utility in $\mathrm{SI-07} \mathrm{(note} \mathrm{that} \mathrm{it} \mathrm{differs} \mathrm{from} \mathrm{the} \mathrm{ecological} \mathrm{usage,} \mathrm{where}$ the 'parafluvial zone' is literally parallel to the river channel; but compare 'paraperiglacial' phenomena, which include RSFs - Mercier 2009). The climatic and geomorphic gradients along and across the eastern Pyrenees present an instructive first opportunity to track the character and distribution of RSF events in both glacial and fluvial valleys, and to identify a spatial transition between paraglacial and parafluvial RSFs.

\subsection{Study area}

The Pyrenees are a compact mountain belt of the Alpine orogeny, some $450 \mathrm{~km}$ long and only 100-150 km wide (Fig. 1), and attain elevations exceeding $3000 \mathrm{~m}$. Structurally, the range comprises an Axial Zone (mainly Palaeozoic basement), flanked by northern and southern thrust zones (mainly Mesozoic sedimentary rocks), with extensive foreland basins beyond. The range is an asymmetric double wedge orogen with a relatively shallow southern slope toward the Ebro foreland basin (Spain), and a steeper northern mountain front producing a sharp border to the Aquitaine-Languedoc foreland basins (France) (Sinclair et al. 2005). The post-orogenic period dates from the Oligocene in the east and Miocene in the west. Present deformation rates are low, and the chain could be considered as an inactive orogen (Lacan and Ortuño 2012). The mountains underwent partial glaciation during the Quaternary, with $75 \%$ of the glaciated area being on the central northern side, which is most exposed to Atlantic weather systems (Taillefer 1977; Calvet et al. 2011). Glaciers only survive, for now, above $\sim 3000$ m.

The study area comprises the eastern third of the Axial Zone, east of Pic d'Estats ( $3143 \mathrm{~m}$ asl) on the main divide (Fig. 1). These eastern Pyrenees were affected by Neogene Mediterranean rifting, and are obliquely dislocated by a NE-SW sequence of faults and intramontane basins (Calvet, 1996; Calvet and Gunnell, 2008; Lacan and Ortuño 2012). The topography has a relatively high mean elevation (over $1500 \mathrm{~m}$ asl), attaining $2900 \mathrm{~m}$ at several points. 
Glaciation incidence varies markedly across the study area (Calvet, 2004). On the north side in the Atlantic catchments, the Würmian equilibrium line altitude (ELA) was at $1400-1800 \mathrm{~m}$ asl, with the Ariège outlet glacier extending $70 \mathrm{~km}$ to reach the piedmont below Foix at $\sim 350 \mathrm{~m}$ asl (Delmas et al. 2011, 2012). To the south and east (Mediterranean catchments), the ELA rose to $2000-2300 \mathrm{~m}$ asl, with the Valira glaciers extending only $20 \mathrm{~km}$, and the eastern plateaux supporting only cirque glaciers or short valley glaciers terminating at $\sim 1200 \mathrm{~m}$ asl in the intermontane basins of Cerdagne and Capcir, with maximum lengths of $20 \mathrm{~km}$ in the Carlit massif. Evidence for a succession of brief advances and unsteady glacier recession suggests a volatile climate, with these maximal extents only attained for short periods (Delmas 2005; Pallàs et al. 2006, 2010; Delmas et al. 2008).

Present-day vegetation below the $\sim 2000 \mathrm{~m}$ treeline is dense forest in the west and north, becoming scrubby in the south and east, where grassland and bare ground are extensive at higher levels. This can be a major, spatially distortive, constraint in RSF identification.

\subsection{Study aims}

Since the study area straddles the main Pyrenean divides and the AtlanticMediterranean climatic transition, includes catchments of both glacial and fluvial character, and encompasses contrasting lithologies, it provides opportunities to:

(1) assess the spatial incidence of RSF across diverse contexts in a compact area;

(2) test the value of RSF as an indicator of concentrated bedrock erosion - or its apparent absence;

(3) examine the contribution of RSF to the destruction of the remnant upland erosion surfaces (paleic relief);

(4) characterise RSF activity across contrasting glacial and fluvial process domains, and evaluate the transition from 'paraglacial' to 'parafluvial' modes.

This reconnaissance study focuses on the spatial incidence of RSF and its role in landscape evolution; it does not deal with geotechnical interpretation of individual sites or with hazard issues. It is concerned with larger-scale RSF events (exceeding the $0.25 \mathrm{~km}^{2}$ threshold of Jarman 2006) rather than lesser rockfalls and landslips. No attempt has been made to date the sites: some show recent or continuing activity, most are assumed to have occurred during or soon after the Würmian deglaciation (cf. Ballantyne and Stone 2013), and some may have occurred during the several Holocene 'paraglacial crises' (cf. André 2003).

The following online Supplementary Information files are provided:

- SI-01 to SI-05 - ppt slide sets for Areas 1-5 as identified on Fig. 1

- SI-06 - fuller descriptions of some principal RSFs

- SI-07 - discussion of the 'parafluvial RSF' concept Individual RSFs are numbered by Area thus: \#101.

\section{RSF identification in the eastern Pyrenees}

By contrast with the Alps, awareness and publication of montane RSF in the Pyrenees has been limited. Local studies include Lebourg et al. (2003) in the French western Pyrenees, and several in the central Spanish Pyrenees (e.g. 
Soeters and Rengers 1983; Bordonau and Vilaplana 1986; Gutierrez-Santolalla et al. 2005, Guerrero et al. 2013). In the study area, the only sub-regional overview, for valley contexts ( $<2000 \mathrm{~m}$ asl) on the southern side of the Pyrenees east of the Noguera catchment, focuses on geological controls and active hazard (Corominas and Baeza 1992). Several landslips and DSGSDs have been investigated and modelled in this sector (Corominas 1990; Hürlimann et al. 2006). On the northern side of the range, geological maps and descriptions have recorded small rockfalls in the Ariège trough, ascribed to postglacial debuttressing (Taillefer 1981, 1982). Extensive RSF has been mapped in and around the Puigmal massif (Llac et al. 1988). Landslide inventories for the three Pyrenean countries now exist (van den Eeckhaut and Hervás 2012), with 274 cases in Andorra alone, but such records tend to report smaller, recent rockfalls and minor landslips in soft materials, typically in riverine and roadside locations. Many of the larger, often relict, montane RSFs of interest to this study appear to have evaded notice. On the 1:300,000 geological map of the eastern Pyrenees (Institut Geologic de Catalunya - www.icgc.cat ), disintegrated RSFs are often accurately delineated, but miscoded as glacial or glacifluvial deposits.

\subsection{Simplified montane RSF typology}

Several international landslide classifications have been elaborated (e.g. Dikau 2004; Hungr et al. 2013) but the three simple types of montane RSF identified for the Scottish Highlands (Jarman 2006; SI-01 slide 2) turn out to serve well in the Pyrenees:

(1) cataclasmic landslide: an event with debris reaching the slope foot/valley floor en masse or as a rock avalanche, often loosely called 'catastrophic'; if the debris remains largely on the slope it is termed 'sub-cataclasmic';

(2) arrested slide: a well defined slipped mass which has travelled a relatively short distance from the source scarp or cavity, and retains much of its fabric; usually translational in competent rocks, more rotational where incompetent; (3) slope deformation (DSGSD): a near-in situ failed mass typically marked by uphill-facing scarplets (antiscarps), sometimes with a split crest (double ridge), and with diffuse margins. It may be 'extensional' if incipient movement with open fractures or creep features is evident; or 'compressional' if quasi-intact with ground ruptures.

These categories recognise the failed rock mass as respectively (1) disintegrated (2) coherent and (3) deformed.

\subsection{RSF identification and verification procedures}

Remote identification of RSF ideally combines large-scale mapping with accurate cartographic depiction of indicative landforms, LiDAR-type DEMs able to 'see' through vegetation cover, and good-definition orthophoto/satellite imagery, each of which has its strengths and weaknesses (Jarman et al. 2011). In both the French and Spanish Pyrenees, the 1:25,000 mapping is precise enough to confirm the topography of known RSFs, but unsuited to identifying any but the boldest cavities, slipped masses, or terrain anomalies. A DEM of sufficient resolution has not been available. In Catalonia, excellent switchable map-orthophoto coverage is accessible at www.icgc.cat, and allows metre-scale dislocations to be confirmed by precise spot-heighting. 
For this study, a preliminary sweep of the French sector was made on Google Earth, utilising its rotate, tilt and continuous zoom facilities to scan valley sides and crest lines from multiple perspectives. Although imagery quality was patchy, with some areas occluded or with poor shadow contrast (SI-01 slide 3), it revealed several prominent features resembling large-scale RSFs. These were then verified in the field, with key indicators recorded (SI-06). Google Earth was then revisited to confirm additional features noted in the field, and to repeat the sweep with benefit of greater awareness of terrain character. This yielded a few additional major new candidate sites; conversely, some sites identified in the field are almost invisible on the imagery. The results of this exercise were then collated with RSF inventories already available for the Spanish and Andorran sectors (but which focussed below $2000 \mathrm{~m}$ asl).

Finally, Google Earth now provides togglable 'historical imagery' of several different dates, which has allowed refinement of the database (e.g. SI-01, slides 65-66, 84-85). In Catalonia, Google Earth utilises the consistently bright www.icc.cat orthophotography; in France, coverage is now high-resolution if often stark (almost black-and-white) with excessive shade on some slopes; only in central Andorra does coverage remain poor. Most of the study area has now been revisited on Google Earth, clarifying some uncertain sites, and successfully extending the inventory into lacunae where RSF was predicted to occur, such as the Vicdessos metasedimentary massif (Fig. 1 area 2B; SI-02).

\subsection{A probability-rated RSF inventory}

Establishing an accurate RSF inventory is bedevilled by both under-recording and false identifications. Sites may elude detection both in the field and on remote imagery if in dense forest, flat light or deep shade. Suspects may be hard to confirm if their features are subtle or their extents ill-defined, or where degraded by glacial over-riding, periglacial weathering, or fluvial erosion. There is much scope for mimicry (e.g. Jarman et al. 2013): here, for example, between arrays of antiscarps and zoogenic lineaments, or between cirques with pendant moraines and cavities with subdued debris lobes. One feature which on Google Earth appeared to be an incipient source fracture proved to be a short section of bulldozed track behind a crest ( $\mathrm{SI}-02$ slide 31 ).

To accommodate this uncertainty, RSFs are rated definite-probable-possible depending on how many criteria they satisfy (as noted in column 3 of the database); this can vary across individual large sites (e.g. SI-01 slide 78). Deformation RSFs should stand out as "landscape anomalies" with, for example, discordant topography, lineament patterns, atypical snow patch patterns, vegetation contrasts, basal springs, or deranged drainage. Field inspection is often essential to confirm remotely-identified suspects. Ideally, sites would be proved by geotechnical investigation (e.g. Davies et al. 2013), but this is usually only practical where serious geohazard exists, as at El Forn, Andorra (Planas and Corominas 2013).

\subsection{Paleic relief}

In detailing the results, many of the RSFs will be noted as associated with the 'paleic relief'. This is the preglacial upland or summit surface traceable in most European mountain ranges - from the South Carpathians (de Martonne 1907), 
Scandinavia (Wråk 1908; Goodfellow 2007), and the Alpine Gipfelflur (Penck and Brückner 1909) to the Scottish Highlands (the surface supérieure of Godard 1965; Jarman 2007). It is typically bevelled across the geology and structure as a plateau or smoothly undulating upland, and may be a peneplain that has undergone tectonic uplift (Ollier and Pain 2000).

In the Pyrenees, much of the paleic relief has been destroyed, primarily by fluvial erosion since Neogene uplift commenced $\sim 10 \mathrm{Ma}$, and by glaciation where cirque development has been sufficient to converge as arêtes. Paleic remnants are rare and small in the west and centre but more evident in the east, This marked gradation is partly climatic, with better preservation in the drier and more lightly glaciated east; but it is also base-level dependent, with surfaces better preserved around the elevated intermontane basins of Cerdagne and Capcir.

In the eastern Pyrenees, paleic remnants of early to middle Neogene age account for $\sim 10 \%$ of the land surface, varying on the higher massifs from $2 \%$ on Puigmal to 16\% on Carlit (Calvet and Gunnell 2008; Gunnell et al. 2009; see SI-01 slide 4). This paleic relief is two-tiered (Calvet 1996): below the summit surface (S), exemplified on Pic Carlit, occurs a population of pediments (surface P1), with some intermediate spurs preserving a paleic character even where the main divides have been glacially sharpened. These fragments may become steep where former valleysides are preserved. RSFs often encroach substantially into paleic remnants; this association is pursued in section 4.3.

\section{Results: sparse RSF in a paraglacial-parafluvial transition}

Within the study area, around 30 principal large-scale montane RSFs and a further 20 lesser or uncertain cases have been identified from the imagery or in the field, with most major sites confirmed by groundtruthing (Fig. 2; Table 1). This surprisingly sparse population affects $45-54 \mathrm{~km}^{2}$ or $1.5-1.8 \%$ of the 3000 $\mathrm{km}^{2}$ glaciated core of the mountain range, with others in fluvial valleys just beyond. Some of the RSFs are nonetheless very substantial in area or landscape impact - seven are 2-5 $\mathrm{km}^{2}$, the largest size found in Britain, although Alpine DSGSDs can attain $10-20 \mathrm{~km}^{2}$. They are evenly distributed across the subcataclasmic, translational slide, extensional deformation and compressional deformation categories RSF types (section 2.1), none being cataclasmic. There are no marked clusters, but they can be grouped in five areas of differing topographic character (Fig. 1; see ppt image sets SI-01 to SI-05 for each area and online $\mathrm{SI}-06$ for fuller descriptions of selected sites). The principal RSFs are numbered by area as in Table 1, thus: \#101).

\section{(1) Carlit massif RSF cluster - a paraglacial domain (Fig. 3; SI-01)}

The massif culminating in Pic Carlit ( $2921 \mathrm{~m}$ ) straddles the main Pyrenean divide, and the Aquitaine-Languedoc divide on its north. The glaciated Ariège-Oriège system incises deeply on its northwest side, whereas on the south and east, glaciation has only partially encroached into the paleic relief, marking a climatic transition.

Three widely separated and contrasting candidate RSFs stood out initially on Google Earth and were verified in the field, with additional sites identified in distant views and from Google Earth rescrutiny: 
\#101 Pic des Llauses RSF (Fig. 4) - A classic extensional slope deformation (DSGSD) of a scale comparable with the Alps. It is the largest-equal RSF identified in the eastern Pyrenees, extending for almost $4 \mathrm{~km}$ along the steep wall of the $1000 \mathrm{~m}$-deep Oriège glacial trough and across the crest into adjacent catchments. It is located just below the transition from the hanging upper Oriège valley into the main fault-guided trough. The berm and antiscarp lineaments are conspicuous if relatively small-scale; parts of the site appear to have progressed to collapse, with debris removed by the valley glacier, leaving cirque-like cavities.

\#102 Sarrat de Coste Rébenc RSF (Fig. 5) - A classic compressional slope deformation, with geometric breakout scarplets across a rare fragment of P1 paleic relief. The site is above the glaciated Orgeix valley, a tributary to the Oriège trough, just outside the threshold of its hanging cirqueform head. It is adjacent to the major east-west Mérens Fault (Fig. 2).

\#103 Pic Carlit E RSF (Fig. 6) - The broad eastern shoulder (Castellà) is cleft for a kilometre by a bold scarp, with the failed and antiscarped mass on the north side having descended at least $30 \mathrm{~m}$, and in places collapsed. It is an extensional deformation which has progressed to arrested translational sliding. The shoulder is a spur of P1 paleic relief character, here some $200 \mathrm{~m}$ wide, effectively halved by the RSF. It flanks the unusually broad if shallow Grava glaciated valley, whose head nearby exhibits two of the rare transfluent glacial breaches in the Pyrenees. Google Earth imagery suggests that a similar suite of features occurs on the broad east shoulder of Pic Péric to the north.

\#104/105 Puymorens RSFs - Two probable large slope deformations have been identified, just outside the deep cirque-head of the Ariège glacial trough (from Google Earth rescrutiny), and a short way down-valley (seen from the roadside opposite and supported by map topography, now confirmed on Google Earth Historical Imagery).

\#106/107 Aston - while the above sites are on metasedimentary rocks, two large RSFs and several lesser possibilities have now been identified from improved Google Earth imagery on the gneiss of the Aston massif.

(2A) Pic des Trois Seigneurs RSF cluster - a paraglacial-parafluvial transition (Fig. 7; SI-02)

The secondary north-slope divide between the Garonne and Ariège catchments (study area boundary) traverses a minor massif between Massat and Tarascon, culminating at Pic des Trois Seigneurs $(2199 \mathrm{~m})$. It is crossed by two cols: the higher, Col de Lers, appears lightly glaciated, but is not a true breach; the lower, Col de Port, is essentially fluvial, where valleyheads meet along a structural weakness. The terrain is markedly transitional, with Pic des Trois Seigneurs having the deep Courbières cirque complex feeding into a ravine on its northeast, but a dendritic fluvial catchment on its north-west; lesser valleys further north display glacially modified upper reaches. RSF occurs freely regardless of valley form, on metasedimentary rocks and migmatites. Key examples are: 
\#201 Pic de Pioulou - A classic failed spur on the flank of the Courbières glacial trough-head, probably slipped from a rim scarp, with antiscarps into the forest and a toe-bulge. The summit above is a dome on an undulating ridge retaining some P1 paleic character.

\#202 Sommet des Griets (Fig. 8a) - An 80x220 m slice of P1 paleic ridge has been lowered by $\sim 5 \mathrm{~m}$ into the moderately glaciated Loumet valleyhead, with lesser failure indications extending for a kilometre along the rim, above a slipped mass with a toe bulge (or Talzuschub) apparently narrowing the valley floor as it becomes fluvial.

\#203 Pic d'Estibat / \#204 Arize RSF suite (Fig. 8b) - Around Col de Port, several cavity-and-lobe configurations occupy south-facing sites in the Massat and Saurat fluvial catchments, with some lobes resembling or evolving into glacial moraines.

(2B) Vicdessos massif - intense glaciation close to the main divide (Fig. 9; SI02)

The deep glacial troughs north of the main divide adjacent to Pic d'Estats ( 3143 $\mathrm{m}$ ), in susceptible metasedimentary rocks, were predicted to display RSFs, which have indeed now become evident on rescrutiny with much sharper current Google Earth. Two landslips have conspicuous lobes/bulges narrowing trough floors (\#253-4), while two probable slope deformations await autoptosis (\#251-2). A kilometre-long split ridge is also noted just west of the study area on a Noguera trough-head spur ( $\mathrm{SI}-02$ slide 50 ).

(3) Puigmal - a weakly-glaciated massif affected by wholesale RSF (Fig. 10a; SI03)

The Puigmal massif ( $2910 \mathrm{~m}$ ) is deeply and extensively incised, with available relief exceeding $1500 \mathrm{~m}$ on all sides. The eastern sector, on gneiss, has glaciated crests and valleyheads, but the remainder, on Cambro-ordovician

metasedimentary rocks, shows very few signs of glaciation (Serrat 1977). Even in the north-facing Eyne trough-head, which has weak cirque features, the last glacier was unable to erode rockslide debris and emplace lodgement till on it. High-level paleic relief survives in the western sector, and was not glaciated (Calvet 1996).

Geological mapping (Llac et al. 1988) records extensive RSF indications, with fractures, landslip scars, and detaching slopes in all the valley heads around Puigmal, together with glacial and periglacial deposits including rock glacier lobes. Google Earth and field imagery confirm these vast RSF complexes, progressing from near-in situ deformation through short-travel slip-masses to debris lobes. The paleic surface of the western sector is succumbing to RSF on most sides (Fig. 10b), with the summit itself being sliced by slip scarps east- and northwards (Fig. 10c). The three valleyheads most obviously dominated by RSF are identified as \#301-303, but its full extent awaits field survey to distinguish scarplets from erosional forms, bedrock from surficial mass movements, and true talus rock glaciers from those which have evolved (often strikingly) from landslide masses (SI-03 slides 15-19). 
On the west side of the Cerdagne basin, the Campcardos massif is essentially similar. The northern parts are in granite and show only minor deformations. On its southwestern shoulder, www.icgc.cat maps and orthophotos now suggest previously unknown very large-scale eastward shoulder-spreading and cirqueslumping from kilometric step-scarps along the $2750 \mathrm{~m}$ asl plateau crest of Serra da Coma Ermada (\#351; Fig. 10d). This site has the greatest available relief of any in the study area $(1230 \mathrm{~m})$.

(4) Andorra - paraglacial RSF in high relief (Fig. 11; SI-04)

On the drier south side of the main W-E divide, large-scale RSF appears, perhaps surprisingly, to be slightly more prevalent than on the north. It occurs in two topographic contexts:

\#401-406 - Glacial trough-head flanks close to the main divide. These are typically compact RSFs where slices of failed summit rim (often quasi-paleic surfaces) occur, sometimes above debris masses previously slipped or collapsed into the side-trough heads (Fig. 12a).

\#409-411 - Flanks of the deeply incised Valira d'Orient system. These include the largest DSGSD in the study area, \#409 Encampadana (Hürlimann et al., 2006), notable for a spreading 'graben' across the plateau shoulder with a large antiscarp below, and the remarkable El Forn RSF (\#410) - at $340 \mathrm{M} \mathrm{m}^{3}$ the largest reported montane RSF volume in the Pyrenees and of Alpine proportions (Corominas and Alonso, 1984; Soutadé 1988; Corominas 1990). It has developed as a $\sim 4 \mathrm{~km}$ long landslip, emerging from a deep cavity to block the valley (Fig. 12b). There are glacial moraines on its foot, indicating overriding by the last glacier during a probably prolonged Pleistocene evolution. It is still active. These RSFs involve cap rocks above Silurian shales which dip valleyward, and weather at depth (to $30 \mathrm{~m}$ at El Forn) to a deformable clayey soil. Both encroach significantly into intermediate paleic relief.

(5) Parafluvial RSF in unglaciated river valleys (Fig. 1; SI-05)

A scatter of substantial RSFs, with a few groups of lesser ones, occurs in the main river valleys beyond the glaciated mountain core. On the north side of the range, where glaciation extended further outward to the piedmont, such valleys are beyond the study area, with minor RSFs mapped in the Mesozoic/Cenozoic foothills (Taillefer 1982). On the south and east, RSF typically occurs where the weak Silurian shales underlie competent Devonian carbonates and other caprocks (\#501-06, 09-10). These are simple landslides in the 'dip-slope' mode of extensive RSF typical of sedimentary uplands (e.g. Apennines of Italy, Pennines of England). Some are partly-rotational slumps evolving into 'earthflow' lobes and tongues, for example in strike valleys of the Freser system (Fleta 1988; Fig. 13a). However, of special interest here are the RSFs of the Tech valley (\#507-08), since they occur on basement metasediments and gneiss, and have closer affinities with those seen in the glaciated mountains.

Several sites are recent or active: \#507 Prats de Mollo is a cataclasmic landslide which blocked the valley in 1940 (Fig. 13b), \#503 Pont de Bar was catastrophically reactivated in 1982 (Rodriguez et al. 1988), and several events 
at \#506 Pardines date between 1690 BP and 1820 BP (Corominas et al 1992). However, the larger sites appear to be 'fossil' with probable pre-Holocene origins: \#508 Arles-sur-Tech is a slope deformation extending well back from the gorge rim into tributary catchments, but with an active lower zone (see notably SI-05 slides 15-16 for colour contrasts in disrupted forest). In the Têt valley, \#510 Serdinya is cut by the T1 (Upper Würm) terrace; other sites in the Aspres region along the Silurian-Devonian contact predate the late or even middle Quaternary. Few if any of these RSFs have been directly caused by active river erosion of their toes: while contemporary catastrophic events such as \#503 Pont de Bar and \#508 Prats de Mollo may be triggered by intense rainfall events $(<1000 \mathrm{~mm} / 24$ hrs) weakening the slopes, they are responding to the longer-term driver of the overall valley incision (i.e the existence of slopes close to critical instability). Thus the Freser and Greixer RSF suites $(\# 504-06,09)$ are essentially rim failures on broad fronts with only some components reaching near the slopefoot (as at \#Nevà, Fig. 13a). Most of this unglaciated river valley group therefore merit being distinguished from purely 'fluvial RSFs' as 'parafluvial RSFs' (see section 4.4 below and $\mathrm{SI}-07$ for fuller discussion).

The sparsity of large-scale RSF in these deep and often sharply incised fluvial valleys is not unusual: the incremental cutting of a narrow slot is evidently insufficient to destabilise slopes in competent rocks. Indeed it is rare for river gorges to be blocked by large landslides in European ranges, although common in ranges such as the Himalaya where uplift is rapid (e.g. Fort 2011).

\section{Discussion}

\subsection{Apparent RSF sparsity is unrelated to standard explanations for RSF incidence}

The single most surprising result is the apparent sparsity of large-scale paraglacial RSF in the eastern Pyrenees, affecting less than $2 \%$ of the $3000 \mathrm{~km}^{2}$ glaciated core of the mountain range (Fig. 2; Table 1). For comparison, in the Alps, $5.6 \%$ of the entire $6200 \mathrm{~km}^{2}$ montane area is affected by DSGSD alone (but including a tail of small sites) (Crosta et al. 2013). In the lesser relief of the Scottish Highlands, two $3500 \mathrm{~km}^{2}$ swaths each have $1.4 \%$ RSF cover, again including a tail of smaller sites (J arman 2006). Even in northern Andorra, RSF only affects $3.4 \%$ of land area, whereas cluster densities commonly reach $5-10 \%$ in the Scottish Highlands.

This apparent sparsity could of course be illusory, for several reasons:

- observational under-recognition, due to dense vegetation cover (but applies to the Alps and many other ranges); remote imagery quality (no longer an issue here); limited field observation time;

- a longer period for RSF degradation since the LGM compared with ranges where most RSF is post-Younger Dryas, especially on steep valleysides exposed to intense precipitation (and possibly periglaciation, although the Pyrenees have been marginal for this (Van Vliet Lanoë and Hallégouët, 1998);

- less space for RSF preservation in narrower, more energetic Pyrenean valleys than in Alpine or Highland troughs; with fluvial erosion this would not apply to slope deformations, and erasure of large rockslides seems unlikely; reglaciation has been suggested at e.g \#101, but applies in all glaciated ranges, e.g. Cook et al. (2013). 
Indeed sparsity can be as instructive as intensity. If any pattern can be found, it may shed light on where erosion has been locally concentrated. First, geology and seismicity, which are commonly invoked to explain RSF distribution (e.g. Ballantyne 2002), but here might explain its sparsity, must be considered.

Geology. Globally, RSF occurs freely on most lithologies, except granites and other durable massive rock types which lack throughgoing discontinuities (Augustinus 1995). In the montane core of the eastern Pyrenees, RSF associates strongly with Cambro-Ordovician metasedimentary terrain (Fig. 2). In the periphery, dip-slip structures control most RSF, where sedimentary cap-rocks overlie weak substrates. While it is unsurprising that RSF is absent from the main granitoid intrusions, gneiss often has tectonic structuring conducive to RSF, e.g. Köfels in the Ötztal Alps (Prager et al. 2009). The Aston massif consists of orthogneiss and paragneiss, yet the handful of RSFs here are on the southern outcrop margin and may be more related to the Mérens Fault. The gneissose half of the Puigmal massif notably lacks RSF.

Even on the metasedimentary lithologies, however, RSF is surprisingly sparse for an alpine environment. One possible factor could be the style of metamorphism, although the evidence is conflicting. Across the Highlands, tectonised or pressuremetamorphosed rocks appear more susceptible than heat-metamorphosed rocks. In northern Scandinavia, flat-lying structure and weakly tectonised thermal metamorphism yield only three significant RSFs in the moderately-glaciated Abisko (Sweden) region (J arman 2002), but a dense RSF cluster in the Kåfjord region (Norway), perhaps due to its context of glacial breaching (Jarman 2009). In the Tirol Alps, RSF occurs very extensively on similarly fissile metasedimentary bedrock (Jarman et al. 2011; Agliardi et al. 2013). In the study area, the Hercynian metamorphic rocks are high-temperature/low-pressure, often in contact settings, generally friable, and with few signs of intense tectonisation and intersecting joint sets. Metamorphic character could thus be a key factor, slightly inhibiting RSF.

Seismicity. Present-day high-magnitude seismic events are often associated with RSF clusters (Keefer 1984), but attempts to interpret paleo-RSF incidence as neotectonic are bedevilled by the need to demonstrate synchronous ages ( $\mathrm{J}$ arman 2006). Here for example, it is tempting to see the sequence of 10 RSFs along the Mérens Fault (Fig. 2; Table 1; SI-01 slide 97) as triggered by major seismic events, but it may simply be an association with a band of metasedimentary and fault-weakened rocks running transverse to deeply-incised valleys.

Likewise, although lineament mapping in the Alps has been suggestive of neotectonic activity (Persaud and Pfiffner 2004), such fractures and scarplets are more probably gravitational or glacio-isostatic rebound structures (Ustaszewski et al. 2008). In the study area, Philip et al. (1992) discuss Quaternary faulting, but field experience and Google Earth scrutiny reveal only subdued or trivial lineaments that could be neotectonic ruptures (e.g. SI-04, slides 9-13). The whole-range inventory of Lacan and Ortuño (2012) lists Quaternary rupture sites at several points along the oblique dislocation linking the Seu d'Urgell-CerdagneCapcir basins, with varying degrees of confidence. Interestingly, one site they note as 'still to be proved' (their structure 26, no precise location or documentation) occurs on the Mérens Fault, where a glacial valley-side and rock glacier are reported as displaced. They suggest that it could be related to glacial 
rebound processes. They also recognise the possibility of gravitational faults (i.e. antiscarps within RSFs) being misidentified as neotectonic structures.

The current seismicity of the Pyrenees is relatively modest, with the western Pyrenees more active (Goula et al. 1999), in what is now regarded as an extensional stress regime involving normal faulting (Chevrot et al. 2011). The tectonic quiescence of the eastern Pyrenees Axial Zone (Lacan and Ortuño 2012, Fig. 1 therein) was interrupted by the 'seismic crisis' of 1427-1428 (Olivera et al. 2006), with three events of magnitudes $M=6-7$ and Mercalli intensities of VIIIIX extending SE from the Puigmal area. However, this is unlikely to account for much of the RSF cluster in that massif, given its extensive evolution into rock glacier complexes which must long predate that crisis.

Paleoseismicity would doubtless have been elevated after deglaciation when glacio-isostatic rebound rates were maximal. However, there is at present no strong evidence associating any of the documented RSFs with seismic triggering.

\subsection{RSF as an indicator of stress concentration at trough-head thresholds}

The most striking spatial finding is that many of the significant paraglacial RSFs in the study area occur at trough-head thresholds. These locations are the transitions from the head of a glacial trough (which may be a cirque, a pronounced hang from a higher valley or upland, or simply a deep trough-head) to the main glaciated valley. The threshold embraces the floor and walls, and is a zone one or a few kilometres long; it may be at grade or hanging. This morphological association arises despite the diverse relief, aspect, structure, and landscape character of the individual topographic sites. The exemplar is Sarrat de Coste Rébenc (\#102), located above a $150 \mathrm{~m}$ riegel transition from the cirqueshaped trough-head into the Orgeix valley (Fig. 14). The Puymorens SW RSF (\#105) occurs just outside the deep Ariège trough-head. The Pic de Pioulou RSF (\#201) is on the shoulder marking the Courbières cirque-ravine transition. The Sommet de Griets RSF (\#202) is positioned at the threshold of the Loumet trough-head cirque. The rockslide opposite Pic de Montcalm (\#253) is similar. The Pic Carlit Castellà RSF (\#103) is on a trough wall just outside a cirque zone flanking the trough-head. In the Eyne valley-head of the Puigmal massif (\#301), the outer RSF elements occur above a glaciated bedrock step near the Würmian terminus of a short valley glacier. In Andorra, Hortell (\#403) and Incles (\#408) exemplify such locations.

In the central Pyrenees south of Lourdes, a dense cluster of large RSF features of all types across low-grade metasedimentary rocks and resistant carbonates (Lebourg et al. 2003). The main group lies just outside the threshold of the classic Cirque de Gavarnie at the head of the Gave de Pau valley (Fort 2013), with a neighbouring group in the Héas trough-head below the Cirque de Troumouse. These are trough-head transitions on a grander scale.

This compelling association between paraglacial RSF and trough-head thresholds suggests that rock mass stresses have been locally exacerbated in such topographic locations. It implies that, at least in recent glacial cycles, cirque or hanging glacier fronts have repeatedly advanced and retreated across this zone, but have only briefly reoccupied the troughs below (Delmas et al. 2008, 2011). The flank walls at these thresholds are thus constantly subjected to an interplay of glacial, glacifluvial, and periglacial processes, including enhanced bedrock erosion of floors and lower slopes. By contrast, RSF is rare on cirque headwalls, 
by virtue of their concave architecture, and because they are buffered by the continuing presence of ice, which only erodes and enlarges them incrementally. Likewise, occasional glacier advances down the trough are short-lived and perform insufficient erosion to provoke RSF on their walls.

Given a relatively small and sparse RSF population, this trough-head threshold association should not of course be overstated. Nonetheless, topographic contexts where cyclical stresses and concentrated bedrock erosion can favour RSF merit geospatial analysis here and in other European ranges (cf. Cossart et al. 2013). Indeed, in the Rodna massif (Romanian Carpathians), a comparable tendency for RSF to occur at the threshold of cirques above fluvial valleyheads has already been noted (Mîndrescu and J arman, unpublished).

\subsection{RSF as concomitant and destroyer of paleic relief}

Nearly all of the principal paraglacial RSFs identified in the study area are adjacent to fragments of the paleic relief (the preglacial summit surface) (Figs 5a, $6 \mathrm{a}, 8 \mathrm{~b} ; \mathrm{SI}-01$ slide 4). Given the sparsity of both landform types, the strength of this association is remarkable. RSF can be seen:

- $\quad$ on the extensive vestiges of summit surface $S$ above $2700 \mathrm{~m}$ at Puigmal and Campcardos, and the shoulder descending from it at \#103 Pic Carlit;

- on tiny residuals of surface $S$ nearer the main divide above $2500 \mathrm{~m}$, where few of the source areas are 'spiky' crests or peaks;

- on lower extents and fragments of surface P1, both near the divides as at \#104-05 Puymorens and more peripherally.

The rationale behind this association between RSF and paleic relief is that crests and horns are inherently more stable than broad ridges above steep troughs (Gerber and Scheidegger 1969), at least in terms of susceptibility to large-scale failure on through-going discontinuities. This phenomenon was observed by Beck (1968) in the New Zealand Southern Alps, where 'pagoda-shaped ridges' in metasedimentary formations are vulnerable to wholesale dismemberment; Puigmal can be so described. A similar close association is seen in the glaciated Highlands (Jarman and Ballantyne 2002) and northern Scandinavia (J arman 2002, 2009), but also in fluvial landscapes in the southern Carpathians.

The association is of course a destructive one, and back-projection implies that RSF has been a more pervasive agent of paleic relief elimination in previous glacial-paraglacial cycles (Jarman 2009). The most striking present encroachment is at Sarrat de Coste Rébenc (\#102), where the entire paleic upper slope is affected by slope deformation (Figs $5 \mathrm{a}, 14$ ): the last surviving fragment in this valley system is thus prepared for elimination probably after the next major glacial advance. The upper Ariège sites (\#104-6) occur on broad shoulders split axially by landslip scarps, potentially halving their widths to more characteristic 'alpine' crests. At Puigmal, the RSF assemblage is much more extensive and disrupted. If hypothetically reinstated it would bring the present $2 \%$ surviving paleic relief (Calvet and Gunnell 2008) back closer to 10\%, thus approaching the extant 16\% of Carlit. The combined effect of sites \#301-303 and surrounding lesser RSFs can only be described as wholesale destruction of the remnant paleic relief.

\subsection{The paraglacial-parafluvial transition}


The results demonstrate that RSF events of similar scale and character can occur within, above, and beyond ice limits (Delmas et al. 2008, 2011), in both glacial and fluvial process domains.

A progression charted for the well-developed glacial landscape of the Scottish Highlands proves broadly valid for the Pyrenees, with the addition of category 3

(Table 2). The end-members are added to frame the concept; purely glacial RSFs are of course not expected to be identifiable in these ranges. The categories are illustrative and not exclusive: placing sites within them simply focuses attention on the extent to which they are responding to glacial or fluvial erosion.

The main transitional areas are thus around Puigmal and Pic des Trois Seigneurs, which are in fluvial catchments with lightly glaciated heads (e.g. Fig. 8), and in the Valira d'Orient, which although glacially modified is markedly narrower than the classic trough-heads which feed it. On a grander scale, just west of the study area in the Noguera de Vallferrera, Google Earth imagery reveals a $7 \mathrm{~km}$ extent of failing ridge in metasedimentary rocks at Pic de Salòria, with slip masses descending NW into a sequence of valleyheads which display a remarkable transition from cirque headwall to dendritic fluvial character as rim elevation declines westwards from 2800 to $2500 \mathrm{~m}$ (SI-04 slides 31-3).

A problem arises with RSFs in fluvial valleyheads: it is easy to see that a slope can be destabilised by a glacier or a major incising river, but the innate feebleness of dendritic headwater streams makes it difficult to see how they can provoke large-scale RSFs. Complex process interactions may be involved, perhaps with glacial erosion obscured by periglaciation or mass movement, or with fluvial discharges enhanced by snowmelt or glacifluvial outburst.

This paraglacial-parafluvial transition in the Pyrenees is matched in other European ranges, notably from the glaciated Alps to the unglaciated Apennines, and in the Carpathians. In the British mountains, the transition is partly from higher to lower terrain but also from the maritime west where glacial dissection is advanced to the continental east where fluvial landscape elements persist.

\section{Sparse, subdued RSF as a tentative indicator of macro-scale geomorphic stability}

Not only is RSF unexpectedly sparse in the eastern Pyrenees, it is unusually subdued on several counts:

- cataclasmic RSFs - the rock avalanches of the Alps and Norway - are absent; the few sub-cataclasmic landslips remain partly within their cavities, with lobes bulging into the valleys, even at El Forn (\#410 - Fig. 12b) and Prats de Mollo (\#508 - Fig. 13b) which created landslide dams (this may partly reflect valleys too narrow to permit full evacuation of cavities);

- antiscarps in the groundtruthed RSFs are generally small scale, under $3 \mathrm{~m}$ in height; only the Encampadana and Incles DSGSDs (\#408-9) compare with the 5-15 m commonly found in other European ranges;

- current RSF activity appears confined to the peripheral river valleys. By contrast, the Alps and Norwegian fjords have experienced numerous large paraglacial RSF events in recent times (Eisbacher and Clague 1984; Blikra et al. 2006). The Pyrenees thus resemble Britain, with no significant paraglacial RSF activity in recorded history; the Highlands have no dated landslides younger than $\sim 1500$ BP (Ballantyne and Stone 2013). Montane RSF in the 
study area thus signals a brief phase of acute disequilibrium around the last deglaciation.

RSFs of hectometric to kilometric scale can be considered a prime indicator of macro-scale geomorphic instability, a high-magnitude if low-frequency response to excessive rockmass stresses induced by locally concentrated or regionally intense erosion of bedrock. In this context, the sparse and subdued incidence of RSF in the Pyrenees might indicate relative geomorphic quiescence - not an obvious state of affairs in a younger mountain range with often strikingly sharp relief. This could reflect two possible factors which are now evaluated: (1) less intense glaciation than in other ranges where paraglacial RSF is prevalent; (2) relative immunity of the montane core from regional base level change, with tectonic uplift rates sufficiently moderate for valley and trough incision to keep pace in a dynamic equilibrium.

\subsection{Evidence of low intensity glaciation}

The Pyrenees have traditionally been viewed as an intensely glaciated range comparable with the Alps, by virtue of the classic cirque-arête landscape of the central peaks. However, the glacial imprint diminishes rapidly away from the main divide. In the study area, even the most glaciated valleys, in the Ariège and Valira systems, remain relatively narrow, irregular and steeply graded, often preserving traces of interlocking spurs with incomplete truncation, and with sections of essentially fluvial gorge (e.g. above Ax). The contrast with the broad troughs of the Alps, the Scottish Highlands, and Scandinavia is marked. Indeed the evidence cited above is that in this marginal, mid-latitude, maritime climate, the main Pyrenean glacial episodes were short-lived pulses (cf. Calvet 2004, Delmas et al., 2008, 2011). Accordingly, the eastern Pyrenees show globally low glacial erosion rates (Delmas et al. 2009).

Sparsity of large-scale RSF on main trough walls is not uncommon in all these ranges, but may be for contrasting reasons. In the Highlands it has been attributed to 'stress hardening' after long adaptation to ice discharge (J arman 2006; cf. McColl 2012), with valley reprofiling having already exploited the slope segments most susceptible to mass failure. In South Tirol, the great Vinschgau trough has negligible RSF on its main walls, but abundant deformations and megafan cavities above the trimline and in hanging tributaries, suggesting minor reshaping of a pre-existing tectonic structure (Jarman et al. 2011).

The main glaciated valley in the study area, the Ariège, appears to lack significant RSF below Puymorens (\#104-5) near its source, despite passing mainly through conducive lithologies. Although the trunk valley ( $\mathrm{Ax}$-Tarascon) has been overdeepened in its middle reaches by $115 \mathrm{~m}$, with the glacier having overtopped its rims in places (Delmas et al. 2012), its irregular course with constrictions between short 'plunge-pools' suggests only partial and gradual adaptation to ice discharge. Its linearity suggests exploitation of a pre-existing fault-controlled valley, with modest bedrock erosion during each glacial cycle insufficient to provoke extensive slope instabilities. A few cavities in resistant cliffs could indicate either fluvial or glacial evacuation of rockslides.

The incision of the Ariège and other valley systems may thus be primarily fluvial and pre-Quaternary, as recorded by the vast expanses of Neogene clastic sequences in the Aquitaine piedmont by comparison with the relatively limited volumes of glacial debris (Stange et al. 2013). The signature location of 
paraglacial RSFs at trough-head thresholds suggests a response to local rather than to regional glacial erosion.

Glacial breaching of main divides is identified as a driver of concentrated erosion and paraglacial RSF in Britain (Jarman 2006), and may apply locally in the Alps and Scandinavia (Jarman 2009; Jarman et al. 2011; Cossart et al. 2014). In the eastern Pyrenees, breaches attributable to glacial transfluence are almost unknown (Fig. 3; SI-01 slide 98), because the icesheet rarely sufficiently overtopped the main divides. The exceptional low breach at Col de Puymorens $(1920 \mathrm{~m})$ is probably a modified preglacial landform; it feeds the Carol/Querol valley, where despite being in granite there are indications on Google Earth of tensional deformation above the precipitous trough walls. Other small, high-level breaches are unlikely to have materially augmented ice throughput.

Relatively weak glaciation in the main valleys, and especially a lack of glacial breaching and thus of concentrated erosion of bedrock in the passes and in troughs down-ice from them, could thus be a contributory factor in Pyrenean RSF sparsity, but hardly a main cause.

\subsection{Evidence of relative tectonic stability}

Globally, RSF incidence is ubiquitous in tectonically dynamic mountain environments, whether entirely fluvial such as Taiwan and Papua New Guinea, or glaciated such as the Himalaya and New Zealand Southern Alps; in these ranges mass movement is often the prime denudation process (Hovius and Stark 2006; Korup et al. 2007). This denudation in turn fuels further isostatic rebound, fluvial and glacial incision, and RSF, diminishing iteratively until the system approaches re-equilibration (Evans 1997; McColl 2012). A corollary might thus be that sparse RSF associates with a weaker tectonic driver.

The eastern Pyrenees have been undergoing progressive tectonic uplift since the Upper Miocene, but at a relatively moderate rate of around $2 \mathrm{~km}$ in $10 \mathrm{Ma}$ or 0.2 $\mathrm{mm} / \mathrm{yr}$ (Calvet and Gunnell, 2008). Uplift of the Apennines has been two to five times greater (Cyr et al. 2010), driving by far the highest RSF densities in Europe - some parafluvial, some simply gravitational, albeit in weak strata (e.g. Guzzetti et al. 2002; Triglia and Iadanza 2008). In the Carpathians, comparable but widely varying long-term uplift rates are cited, with emerging evidence of RSF clusters in their crystalline cores driven by areal fluvial denudation. In the European Alps, where uplift is primarily glacio-isostatic, RSF is extensive in great troughs such as the Upper Rhône and Val Tellina, possibly reflecting a positive feedback between Quaternary bulk erosion, rebound, and regional tectonic buoyancy (Sue et al. 2007). Interestingly, DSGSD incidence associates with high rather than very high rebound rates, re-incision having not been able to keep pace with the latter (Agliardi et al. 2013).

It would thus seem that Pyrenean tectonic uplift has been insufficient during the later Quaternary to generate the slope stresses necessary to provoke extensive bedrock mass movement. The landscape evolution of the Pyrenees has to be reconsidered in this light.

The primary driving force behind fluvial incision in the Pyrenees is Neogene tectonic uplift (Gunnell et al. 2009). However its effectiveness is dependent on the connectivity of the drainage systems to drops in regional and local base levels: if static knickpoints or intramontane basins impede headward channel- 
profile steepening, the inner mountain cores can remain immune from dissection (cf. Bishop 2007; Calvet et al. 2013).

In the eastern Pyrenees, the northern and southern thrust zones bracket the montane core with knickpoints. Only the easternmost rivers drain more directly to the Mediterranean, where however even intense eustatic changes such as the Messinian salinity crisis do not appear to have propagated deep into the mountain range. A tripartite landscape response to tectonic history thus comprises:

- a steeper, more abrupt north slope deeply dissected by the Ariège system in particular, and to a lesser extent the Aude, possibly having displaced the range divide at their heads southwards by $\sim 10 \mathrm{~km}$;

- a south slope dissected by the Segre and Freser systems, but to somewhat higher local base levels, e.g. (at similar distances from the range divide) La Seu d'Urgell, $727 \mathrm{~m}$ (Segre), versus Tarascon, $479 \mathrm{~m}$ (Ariège);

- the elevated semi-internal basins of Cerdagne and Capcir setting local base levels to surrounding massifs at $\sim 1200-1600 \mathrm{~m}$ asl.

The Puigmal massif illustrates the difficulties in pursuing the influence of baselevel controls. It drains partly direct to the southern and eastern river gorges and partly via the Cerdagne basin. Two of the RSF complexes destroying its western summit surface are in valleys graded to the $1300 \mathrm{~m}$ asl base level of that basin, with the third draining to the Freser ( $900 \mathrm{~m}$ asl at equivalent distance). The Puigmal massif has an anomalously active tectonic history during the late Neogene (Calvet 1996, Calvet and Gunnell 2008) and may have been elevated relative to the Cerdagne basin.

The dissection of the western Puigmal massif is clearly being fed by extensive RSF in the headwaters, in the manner described by Hovius and Stark (2006), despite headwater erosion being inherently weak. The way in which such massifs are being destabilised by extensional and unloading stresses generated by long-term tectonic uplift and bulk erosion needs to be better understood (cf. Calvet 1999). Generally, the sparsity and locational specificity of RSF across all three east Pyrenean landscape evolution zones could suggest that late Neogene incision has merely been keeping pace with uplift, or has yet to propagate effectively into the montane core from the existing 'fall line' to these knickpoints, and that the slope system (at least since the Last Glacial Maximum, to which the extant RSF inheritance relates) is close to dynamic equilibrium.

\section{Conclusions}

This overview of large-scale RSF character and spatial incidence in the eastern Pyrenees identifies a number of hypotheses to account for its apparent sparsity and for the specific geomorphic settings with which it associates. These hypotheses will benefit from refinement with geostatistical analysis, morphometric mapping, reappraisal of tectonicity and landscape evolution, and of course closer field investigation. We provisionally conclude:

(1) RSF appears to be relatively scarce and subdued in the eastern Pyrenees by comparison with other European ranges, although the existence of some bold and extensive sites confirms the potential for it.

(2) RSF incidence follows no obvious regional pattern or clustering. RSF occurs in steep, narrow glaciated upper valleys in the Ariège and Valira catchments with ambient relief of $800-1000 \mathrm{~m}$; in moderately glaciated contexts, such as east Carlit, with only $400 \mathrm{~m}$ available relief; in minimally glaciated mountains 
such as Puigmal, where massif relief attains $1500 \mathrm{~m}$; in modest foothills around Col de Port; and in the non-glaciated peripheral river valleys.

(3) As elsewhere in Europe, there is a partial geological control, with most RSF occurring on metasedimentary rocks or Silurian shales, but with some on carbonates, migmatite, gneiss, and granite margins. The scatter of often isolated RSFs implies a response to specific combinations of local factors. A sequence of 10 RSFs along the Mérens Fault could be seismically-triggered, or simply exploiting weaker rocks.

(4) In glaciated valleys, RSFs are located preferentially at trough-head thresholds, between the cirques and the main valleys. Erosion and other stresses may have been concentrated around these thresholds during repeated cirque glacier advances, which only seldom or briefly progressed further down the main valleys.

(5) In the montane areas, RSF is strongly associated with vestiges of preglacial topography, which are inherently more vulnerable to rock mass stresses. RSF is contributing significantly to the progressive elimination of this paleic relief.

(6) In the Pyrenees it is possible to identify both paraglacial RSF and parafluvial RSF, with a transition between them. An important distinction is also made between fluvial RSFs, which are an integral part of river erosion, and parafluvial RSFs, which are on slopes in fluvial process domains but occur above the direct influence of rivers.

(7) RSF sparsity and subdued character may reflect the moderate to weak imprint of glacial erosion and a lack of glacial breaching, but this can only be a partial explanation since RSF is abundant in many non-glaciated ranges.

(8) The concept of 'concentrated erosion of bedrock' engendering elevated rebound stresses within troughs and breaches, which assists in accounting for RSF spatial incidence in some other ranges, cannot be corroborated in the study area.

(9) An underlying signal of tectonic forcing might be associated with the broad fluvial denudation of recently uplifting massifs such as Puigmal, hence its wholesale destruction by RSF.

(10) Overall RSF sparsity may be a consequence of low mean rates of later Neogene tectonic uplift, combined with knickpoints and intramontane basins isolating the core massifs from vigorous dissection. It might indicate that combined fluvial and glacial erosion have been insufficient to destabilise slopes and generate rebound on the scale required to provoke large-scale $\mathrm{RSF}$, in a landscape not far from dynamic equilibrium.

David J arman, Mountain Landform Research, Scotland david.jarman914@virgin.net

\section{ACKNOWLEDGMENTS}

Stephan Harrison for many discussions leading to co-presentation of the paraglacial-parafluvial transition concept; Sam McColl for a thought-provoking review and many detailed improvements; two anonymous reviewers for prompting important clarifications; Jasper Knight for initial encouragement and a close reading of the text; Denis Mercier for several valuable comparisons; the organisers of IAG 2013 Paris, which helped animate this paper and further internationalise its scope. 


\section{REFERENCES}

Agliardi, F., Crosta, G.B., Frattini, P. and Malusà, M.G., 2013. Giant noncatastrophic landslides and the long-term exhumation of the European Alps. Earth and Planetary Science Letters, 365, 263-274.

André, M. F., 2003. Do periglacial landscapes evolve under periglacial conditions?. Geomorphology, 52, 149-164.

Augustinus, P.C., 1995. Rock mass strength and the stability of some glacial valley slopes. Zeitschrift für Geomorphologie, 39, 55-68.

Ballantyne, C.K., 2002. Paraglacial geomorphology. Quaternary Science Reviews, 21, 1935-2017.

Ballantyne, C.K. and Stone, J.O., 2013. Timing and periodicity of paraglacial rock-slope failures in the Scottish Highlands. Geomorphology, 186, 150-161. Ballantyne, C.K., Sandeman, G.F., Stone, J.O. and Wilson, P., 2014. Rock-slope failure following Late Pleistocene deglaciation on tectonically stable mountainous terrain. Quaternary Science Reviews, 86, 144-157.

Beck, A.C., 1968. Gravity faulting as a mechanism of topographic adjustment. New Zealand J ournal of Geology and Geophysics, 11, 191-199.

Bishop, P., 2007. Long-term landscape evolution: linking tectonics and surface processes. Earth Surface Processes and Landforms, 32, 329-365.

Bjerrum, L. and Jørstad, F.A., 1968. Stability of rock slopes in Norway. Norwegian Technical Institute, Publ. No. 69.

Blikra, L.H., Longva, O., Braathen, A., Anda, E., Dehls, J.F. and Stalsberg, K., 2006. Rock slope failures in Norwegian fjord areas: examples, spatial distribution and temporal pattern. In: Evans, S.G., Mugnozza, G.S., Strom, A. and Hermanns, R.L. (eds), Landslides from massive rock slope failure. Springer, Dordrecht, 475496.

Bordonau, J. and Vilaplana, J.M., 1986. Géomorphologie et tectonique récente dans le Val d'Aran (Zone axiale des Pyrénées Centrales, Espagne). Revue de Géologie Dynamique et de Géographie Physique, 27, 303-310.

Burbank, D.W. and 6 others, 1996. Bedrock incision, rock uplift and threshold hillslopes in the northwestern Himalayas. Nature, 379, 505-510.

Calvet, M., 1996. Morphogenèse d'une montagne méditerranéenne, les Pyrénées orientales. Documents du BRGM, vol. 255, 3 t., 1177 p..

Calvet M., 1999. Régime des contraintes et volumes de relief dans l'Est des Pyrénées. Géomorphologie: relief, processus, environnement, 3, 253-278.

Calvet, M., 2004. The Quaternary glaciation of the Pyrenees. In: Ehlers J., Gibbard P. (eds) Quaternary Glaciations - Extent and Chronology, part I : Europe. Elsevier, 119-128.

Calvet, M. and Gunnell, Y., 2008. Planar landforms as markers of denudation chronology: an inversion of East Pyrenean tectonics based on landscape and sedimentary basin analysis. In: Gallagher, K., Jones, S.J. and Wainwright, J. (eds), Landscape evolution: denudation, climate and tectonics over different time and space scales. Geological Society, London Special Publication, 296, 147-166. Calvet, M., Delmas, M., Gunnell, Y., Braucher, R. and Bourlès, D., 2011. Recent advances in research on Quaternary glaciations in the Pyrenees. In: Ehlers, J. and Gibbard, P.L. (eds), Quaternary Glaciations, Extent and Chronology, A Closer Look. Part IV. Elsevier, Amsterdam, pp. 127-139. 
Calvet, M., Gunnell, Y. and Delmas, M., 2008. Géomorphogenèse des Pyrénées. In: Canerot, J., Colin, J.P., Platel, J.P. and Bilotte, M. (eds), Pyrénées d'hier et d'aujourd'hui. Atlantica, Biarritz, 129-143.

Calvet, M., Gunnell, Y. and Delmas, M., 2013. The Têt river valley: a condensed record of long-term landscape evolution in the Pyrenees. In Fort, M. and André, M.F. (eds), Landscapes and Landforms of France. Springer, Dordrecht, 127-138. Chevrot, S., Sylvander, M. and Delouis, B., 2011. A preliminary catalog of moment tensors for the Pyrenees. Tectonophysics, 510, 239-251.

Cook, S.J., Porter, P.R. and Bendall, C.A., 2013. Geomorphological consequences of a glacier advance across a paraglacial rock avalanche deposit. Geomorphology, 189, 109- 120.

Corominas, J., 1990. Influencia del glacialismo cuaternario en la estabilidad de las laderas del valle del Valira d'Orient (Andorra). I Reunión Nacional de

Geomorfologia, Teruel, 521-532.

Corominas, J. and Alonso, E., 1984. Inestabilidad de laderas en el Pirineo Catalán. Tipología y causas. Ponencias y comunicaciones de las J ornadas de Trabajo sobre la Inestabilidad de laderas en el Pirineo. Barcelona. C.1-C.53.

Corominas, J. and Baeza, C., 1992. Landslide occurrence in Eastern Pyrenees. In: M. Del Prete (ed.), Movimenti franosi e metodi di stabilizzazione. Consiglio Nazionalle delle Ricerche, Publicazione 481, 25-42.

Corominas, J.; Fleta, J.; Goula, X.; Moya, J. and Teixidor, T., 1992. Datación de deslizamientos antiguos en el area de Pardines (Girona). 3r Simposio Nacional sobre Taludes y Laderas Inestables. La Coruña. Vol. 1, 71-82

Corominas J., Planas X. and Turu V., 2013. Stop 22, Canillo Belvedere-Cap de Quer. In: Calvet, M., Gunnell, Y. and Delmas, M. (eds), Geomorphology of the Pyrenean orogen. 8th IAG International Conference on Geomorphology, Postconference field excursion ,10, 129-132.

Cossart, E., Mercier, D., Decaulne, A. and Feuillet, T., 2014. An overview of the consequences of paraglacial landsliding on deglaciated mountain slopes: typology, timing and contribution to cascading fluxes. Quaternaire, 1, 13-24.

Cossart, E., Mercier, D., Decaulne, A., Feuillet, T., Jónsson, H.P. and

Sæmundsson, P., 2013. Impacts of post-glacial rebound on landslide spatial distribution at a regional scale in northern I celand (Skagafjörður), Earth Surface Processes and Landforms, 39, 336-350.

Crosta, G.B. and Zanchi, A., 2000. Deep seated slope deformations - huge, extraordinary, enigmatic phenomena. In: Bromhead, E., Dixon, N. and Ibsen, M. (eds), Landslides in research, theory and practice. Proceedings of the $8^{\text {th }}$ International Symposium on Landslides, Cardiff, June 2000. Thomas Telford, London, 351-358.

Crosta, G.B., Frattini, P. and Agliardi, F., 2013. Deep seated gravitational slope deformations in the European Alps. Tectonophysics, 605, 13-33.

Cyr, A.J., Granger, D.E., Olivetti, V. and Molin, P., 2010. Quantifying rock uplift rates using channel steepness and cosmogenic nuclide-determined erosion rates: Examples from northern and southern Italy. Lithosphere, 2, 188- 198.

Davies, T.R., Warburton, J., Dunning, S.A. and Bubeck, A.A., 2013. A large landslide event in a post-glacial landscape: rethinking glacial legacy. Earth Surface Processes and Landforms, 38, 1261-1268.

Delmas, M., 2005. La déglaciation dans le massif du Carlit (Pyrénées orientales): approches géomorphologique et géochronologique nouvelles. Quaternaire, 16, 45-55. 
Delmas, M., Gunnell, Y., Braucher, R., Calvet, M. and Bourlès D., 2008. Exposure age chronology of the last glacial cycle in the eastern Pyrenees. Quaternary Research, 69, 231-241.

Delmas, M., Calvet, M., and Gunnell, Y., 2009. Variability of erosion rates in the Eastern Pyrenees during the last glacial cycle - a global perspective on the impact of glacial erosion on mountain landscapes. Quaternary Science Reviews, 28, 484-498.

Delmas, M., Calvet, M., Gunnell, Y., Braucher, R., and Bourlès, D., 2011. Palaeogeography and ${ }^{10} \mathrm{Be}$ exposure-age chronology of Middle and Late Pleistocene glacier systems in the northern Pyrenees: implications for reconstructing regional palaeoclimates. Palaeogeography, Palaeoclimatology, Palaeoecology, 305, 109-122.

Delmas, M., Calvet, M., Gunnell, Y., Braucher, R., and Bourlès, D., 2012. Les glaciations quaternaires dans les Pyrénées ariégeoises: approche historiographique, données paléogéographiques et chronologiques nouvelles. Quaternaire, 23, 61-85.

Delmas, M., Gunnell, Y. and Calvet, M., 2014. Environmental controls on alpine cirque size. Geomorphology, 206, 318-329.

Dikau, R., 2004. Mass movement. In Goudie, A. (ed.), Encyclopedia of Geomorphology. Routledge, London, 644-653.

Dühnforth, M., Anderson, R. S., Ward, D. and Stock, G. M., 2010. Bedrock fracture control of glacial erosion processes and rates. Geology, 38, 423-426. Eeckhaut, M. van den and Hervás, J. 2012. State of the art of national landslide databases in Europe and their potential for assessing landslide susceptibility, hazard and risk. Geomorphology, 139-140, 545-558.

Eisbacher, G.H. and Clague, J.J., 1984. Destructive mass movements in high mountains: hazard and management. Geological Survey of Canada Professional Paper, 84/16.

Evans, I.S., 1997. Process and form in the erosion of glaciated mountains. In: Stoddart, D.R. (ed.), Process and form in geomorphology. Routledge, London, 145- 174.

Fleta Pastor J., 1988. Lithologias y deslizamientos en la cuenca alta del rio Ter. In: Alonso E. and Corominas J. (eds) II Simposio Sobre taludes y laderas inestables, Andorra, 9-11 de marzo de 1988, p. 31-40, CYAN edit.

Fort, M., 2011. Two large late Quaternary rock slope failures and their geomorphic significance, Annapurna Himalayas (Nepal). Geografia Fisica e Dinamica Quaternaria, 34, 5-16.

Fort, M., 2013. The Gavarnie Cirque: A Celebrated "Nature's Colossus". In: Fort, M. and André, M.-F. (eds), Landscapes and Landforms of France. Springer, Dordrecht, 115-126.

Gerber, E. and Scheidegger, A.E., 1969. Stress-induced weathering of rock masses. Eclogae Geologicae Helveticae, 62, 401-415.

Gjessing, J., 1967. Norway's paleic surface. Norsk Geografisk Tidsskrift, 21, 69132.

Godard, A., 1965, Recherches de Géomorphologie en Écosse du Nord-Ouest. Université de Strasbourg, Publications de la Faculté des Lettres, Fondation Baulig. Goodfellow, B.W., 2007. Relict non-glacial surfaces in former glaciated landscapes. Earth-Science Reviews, 80, 47-73. 
Goula, X., Olivera, C., Fleta, J., Grellet, B., Lindo, R., Rivera, L., Cisternas, A. and Carbon, D., 1999. Present and recent stress regime in the eastern part of the Pyrenees. Tectonophysics, 308, 487-502.

Gregersen., S. and Basham, P., 1989. Earthquakes at North Atlantic passive margins: neotectonics and postglacial rebound. Kluwer, Dordrecht.

Guerrero, J., Gutiérrez, F., Carbonel, D., Bonachea, J., García-Ruiz, J.M., Galve, J.P. and Lucha, P., 2013. 1:5000 landslide map of the upper Gállego Valley (central Spanish Pyrenees). Journal of Maps 8, 484-491.

Gunnell, Y., Calvet, M., Brichau, S., Carter, A., Aguilar, J.P. and Zeyen, H., 2009. Low long-term erosion rates in high-energy mountain belts: insights from thermo- and biochronology in the Eastern Pyrenees. Earth and Planetary Science Letters, 278, 208-218.

Gutierrez-Santolalla, F., Acosta, E., Santiago, R., Guerrero, J. and Lucha, P., 2005. Geomorphology and geochronology of sackung features (uphill-facing scarps) in the Central Spanish Pyrenees. Geomorphology, 69, 98-314.

Guzzetti, F., Malamud, B.D., Turcotte, D.L. and Reichenbach, P., 2002. Power-law correlations in landslide areas in central I taly. Earth and Planetary Science Letters, 195, 169-183.

Heim, A., 1932. Bergsturz und Menschenleben. Fretz und Wasmuth, Zurich. Hovius, N. and Stark, C.P., 2006. Landslide-driven erosion and topographic evolution of active mountain belts. In: Evans, S.G., Mugnozza, G.S., Strom, A. and Hermanns, R.L. (eds), Landslides from massive rock slope failure. Springer, Dordrecht, 573-590.

Hovius, N., Stark, C.P. Chu, H.T. and Lin, J.C., 2000. Supply and removal of sediment in a landslide-dominated mountain belt: Central Range, Taiwan. Journal of Geology, 108, 73-89.

Hungr, O., Leroueil, S. and Picarelli, L., 2013. The Varnes classification of landslide types, an update. Landslides DOI 10.1007/s10346-013-0436-y. Hürlimann, M., Ledesma, A., Corominas, J. and Prat, P.C., 2006. The deep-seated slope deformation at Encampadana, Andorra: representation of morphologic features by numerical modelling. Engineering Geology, 83, 343-357.

Hutchinson, J.N., 1988. General report: morphological and geotechnical parameters of landslides in relation to geology and hydrogeology. Proceedings $5^{\text {th }}$ Int. Symposium on Landslides, Lausanne, vol. 1. Balkema, Rotterdam, 3-35. Jarman, D., 2002. Rock slope failure and landscape evolution in the Caledonian Mountains, as exemplified in the Abisko area, northern Sweden. Geografiska Annaler, Series A: Physical Geography, 84, 213-224.

Jarman, D., 2006. Large rock slope failures in the Highlands of Scotland: characterisation, causes and spatial distribution. Engineering Geology, 83, 161182.

Jarman, D., 2007. Alain Godard on the NW Highlands of Scotland: present relevance for long-term landscape evolution studies. Géomorphologie: relief, processus, environnement, 177-203.

Jarman, D., 2008. The Roy-Lochy rock slope failure cluster: implications for glacial breaching, ice movements, and Parallel Road dislocations. In: Lowe, J.J., Rose, J. and Palmer, A. (eds), The Quaternary of Glen Roy and vicinity - Field Guide. Quaternary Research Association, London, 98-104. Jarman, D., 2009. Paraglacial rock slope failure as an agent of glacial trough widening. In: Knight, J. and Harrison, S. (eds), Periglacial and paraglacial 
processes and environments. Geological Society of London Special Publication, 320, 103-131.

Jarman, D. and Ballantyne, C.K., 2002. Beinn Fhada, Kintail: a classic example of paraglacial rock slope deformation. Scottish Geographical J ournal, 118, 59-68. Jarman, D., Agliardi, F. and Crosta, G., 2011. Megafans and outsize fans from catastrophic slope failures in alpine glacial troughs: the Malser Haide and the Val Venosta cluster, Italy. In: Jaboyedoff, M. (ed.), Slope Tectonics. Geological Society of London Special Publication, 351, 253-278.

Jarman, D., Wilson, P. and Harrison, S., 2013. Are there any relict rock glaciers in Britain? J ournal of Quaternary Science, 28, 131-143.

Jarvis A., Reuter H.I., Nelson A. and Guevara E., 2008. Hole-filled seamless SRTM data V4, International Centre for Tropical Agriculture ( $\mathrm{CIAT})$, available from http://srtm.csi.cgiar.org

Keefer, D.K., 1984. Landslides caused by earthquakes. Geological Society of America Bulletin, 95, 406-421.

Koppes, M. N. and Montgomery, D. R., 2009. The relative efficacy of fluvial and glacial erosion over modern to orogenic timescales. Nature Geoscience, 2, 644647.

Korup, O., Clague, J.L., Hermanns, R.L., Hewitt, K., Strom, A.L. and Weidinger, J.T., 2007. Giant landslides, topography, and erosion. Earth and Planetary Science Letters, 261, 578-589.

Lacan, P. and Ortuño, M., 2012. Active Tectonics of the Pyrenees: a review. Journal of I berian Geology 38, 9-30.

Lebourg, T., Fabre, R., Clement, B. and Frappa, M., 2003. High-mountain landslides in the Atlantic Pyrenees: their relationship with the geology and geomorphology. Bulletin of Engineering Geology and the Environment, 62, 221229.

Llac, F., Autran, A., Guitard, G., Robert, J.F., Gourinard, Y. and Santanach, P., 1988. Carte géologique de la France (1:50,000). Sheet Saillagouse (1098).

Orléans, BRGM edit. Notice explicative par F. Llac (1989), 75 p.

De Martonne, E., 1907. Recherches sur l'évolution morphologique des Alpes de Transylvanie. Delagrave, Paris.

McColl, S.T., 2012. Paraglacial rock-slope stability. Geomorphology, 153-154, 116.

Mercier, D., 2009. Paraglacial and paraperiglacial landsystems: concepts, temporal scales and spatial distribution. Géomorphologie: relief, processus, environnement, 2008, 223-233.

Mollard, J.D., 1977. Regional landslide types in Canada. In: Coates, D.R. (ed.), Landslides. Reviews in Engineering Geology (Geological Society of America), 3, 29-56.

Olivera, C., Redondo, E., Lambert, J., Riera Melis, A. and Roca, A., 2006. Els terratrèmols dels segles XIV i XV a Catalunya. Institut Cartogràfic de Catalunya, Monografies, 30, 407p.

Ollier, C. and Pain, C., 2000. The origin of mountains. Routledge, London. Pallàs, R., Rodés, A., Braucher, R., Carcaillet, J., Ortuño, M., Bordonau, J., Bourlès, D., Vilaplana, J.M., Masana, E. and Santanach, P., 2006. Late Pleistocene and Holocene glaciation in the Pyrenees: a critical review and new evidence from ${ }^{10} \mathrm{Be}$ exposure ages, south-central Pyrenees. Quaternary Science Reviews, 25, 2937-2963. 
Pallàs, R., Rodès, A., Braucher, R., Bourlès, D., Delmas, M., Calvet, M. and Gunnell, Y., 2010. Small, isolated glacial catchments as priority target for cosmogenic surface dating of Pleistocene climate fluctuations, SE Pyrenees. Geology, 38, 891-894.

Penck, A. and Brückner, E., 1909. Die Alpen im Eiszeitalter. Tauchnitz, Leipzig. Persaud, M. and Pfiffner, O.A., 2004. Active deformation in the eastern Swiss Alps: Post-glacial faults, seismicity and surface uplift. Tectonophysics, 385, 5984.

Philip, H., Bousquet, J.-C., Escuer, J., Fleta, J., Goula, X. and Grellet, B., 1992. Présence de failles inverses d'âge quaternaire dans l'est des Pyrénées: implications sismotectoniques. Comptes Rendus de L'Académie des Sciences, Paris, série II, 314, 1239-1245.

Poschinger, A. von, 2002. Large rockslides in the Alps: a commentary on the contribution of G. Abele (1937-1994) and a review of some recent developments. In: Evans, S.G. and de Graaff, J.V. (eds), Catastrophic landslides: effects, occurrence and mechanisms. Reviews in Engineering Geology (Geological Society of America), 15, 237-255.

Prager, C., Zangerl, C. and Nagler, T., 2009. Geological controls on slope deformations in the Köfels rockslide area (Tyrol, Austria). Austrian Journal of Earth Sciences 102, 4-19.

Rodriguez Ortiz, J.M., Hinojosa Cabrera, J.A. and Castanedo Navarro, F.J., 1988.

El dezlizamiento de Pont de Bar (Lerida) de octubre de 1982. In: Alonso E., Corominas, J. (eds) II Simposio Sobre taludes y laderas inestables, Andorra, 9-11 de marzo de 1988, CYAN, 693-703,

Serrat, D., 1977. Estudio Geomorphologico del Pirineo oriental (PuigmalCostabona), Univ. Central Barcelona, $221 \mathrm{p}$.

Sinclair, H.D., Gibson, M., Naylor, M. and Morris, R.G., 2005. Asymmetric growth of the Pyrenees revealed through measurement and modeling of orogenic fluxes. American J ournal of Science, 305, 369-406.

Soeters, R. and Rengers, N., 1983. Dos ejemplos de hundimientos gravitacionales en los alrededores de Caldes de Boí (Pirineos Leridanos). Libro Jubilar J.M. Rios. IGME, Madrid. Tomo III, 192-202.

Soutadé, G., 1988. Le glissement d'el Forn (Andorre). $11^{\circ}$ Simposio Inestabilidad de Taludes y Laderas Naturales, Andorra la Vella, 643-655.

Stange, K.M., van Balen, R.T., Kasse, C., Vandenberghe, J. and Carcaillet, J., 2014. Linking morphology across the glaciofluvial interface: a ${ }^{10} \mathrm{Be}$ supported chronology of glacier advances and terrace formation in the Garonne River, northern Pyrenees, France. Geomorphology, 207, 71-95.

Stewart, I.S., Sauber, S. and Rose, J., 2000. Glacio-seismotectonics: ice sheets, crustal deformation and seismicity. Quaternary Science Reviews 19, 1367-1389.

Sue, C., Delacou, B., Champagnac, J.-D., Allanic, C., Tricart, P. and Burkhard, M., 2007. Extensional neotectonics around the bend of the Western/Central Alps: an overview. International J ournal of Earth Sciences, 96, 1101-1129.

Taillefer, F., 1977. Le glacier de l'Ariège dans le bassin de Tarascon. Revue Géographique des Pyrénées et du Sud-Ouest, 48, 269-286.

Taillefer F., 1981. Le périglaciaire des Pyrénées ariégeoises: grands éboulements et éboulis lités. Recherches Géographiques à Strasbourg, 1 (16-17), 131-136. Taillefer, F., 1982. Eboulements quaternaires du Plantaurel et du Pech de Foix. Bulletin de la Société d'Histoire Naturelle de Toulouse, 118, 111-123. 
Tonini, M., Pedrazzini, A., Penna I. and Jaboyedoff, M., 2013. Spatial pattern of landslides in Swiss Rhône Valley. Natural Hazards, 1-14.

Triglia, A. and Iadanza, C., 2008. Landslides in Italy: special report. ISPRA, Rome.

Ustaszewski, M.E., Hampel, A. and Pfiffner, O.A., 2008. Composite faults in the Swiss Alps formed by the interplay of tectonics, gravitation and postglacial rebound: an integrated field and modelling study. Swiss J ournal of Geosciences, 101, 22- 235.

Van Vliet Lanoë, B. and Hallégouët, B., 1998. Cartographie ANDRA-CNF-INQUA 1999.

Wilson, P., Clark, R. and Smith, A., 2004. Rock-slope failures in the Lake District: a preliminary report. Proceedings of the Cumberland Geological Society, 7, 1336.

Wråk, W., 1908. Bidrag till Skandinaviens reliefkronologi. Ymer 28, 141-191. Zischinsky, U., 1966. On the deformation of high slopes. International Society of Rock Mechanics, First Congress Proceedings, vol. 2, 179-185.

Manuscript Received d mmm., 20yy, revised and accepted d mmm., 20yy

TABLE 1 - separate attachment, landscape format

TABLE 2 The (glacial-) paraglacial-parafluvial (-fluvial) RSF typological transition

\begin{tabular}{|c|c|c|c|}
\hline & $\begin{array}{l}\text { morphological } \\
\text { context }\end{array}$ & indicative description & Pyrenees sites \\
\hline 1 & glacial & $\begin{array}{l}\text { undercut by, falling onto, and (usually) } \\
\text { exported by glaciers }\end{array}$ & (\#101 partly exported?) \\
\hline 2 & paraglacial & $\begin{array}{l}\text { on or above a glaciated valleyside (sensu } \\
\text { Ballantyne 2002) }\end{array}$ & $\begin{array}{l}\text { \#101-107 \#251,253-54 } \\
\# 401-08\end{array}$ \\
\hline 3 & $\mathrm{v}$ & on a weakly glaciated valleyside & \#301-303, 351 \#409-10 \\
\hline 4 & $\mathrm{v}$ & $\begin{array}{l}\text { above a fluvial incision within a glacial trough } \\
\text { floor }\end{array}$ & \#252 \\
\hline 5 & $v$ & above a fluvial incision into a glacial trough wall & \\
\hline 6 & $\mathrm{v}$ & $\begin{array}{l}\text { above a transition from glacial to fluvial valley } \\
\text { or v.v. }\end{array}$ & \#201-02,05 \\
\hline 7 & $\mathrm{v}$ & $\begin{array}{l}\text { above a fluvial valley but close to a hang into a } \\
\text { glacial trough }\end{array}$ & \#411 \\
\hline 8 & $\mathrm{v}$ & $\begin{array}{l}\text { above a fluvial headwater incising into a glacial } \\
\text { trough-head }\end{array}$ & \\
\hline 9 & parafluvial & $\begin{array}{l}\text { on a fluvial valleyside but above direct influence } \\
\text { of rivers }\end{array}$ & \#203-04 \#502-10 \\
\hline 10 & fluvial & $\begin{array}{l}\text { undercut by, falling into, and (being) washed } \\
\text { away by rivers }\end{array}$ & $\begin{array}{l}\# 501 \\
\text { (\#507 is into river) } \\
\text { (several deflect river) }\end{array}$ \\
\hline & (also) & & \\
\hline 11 & paraglacifluvial & above a glacifluvial channel & \\
\hline 12 & paraperiglacial & $\begin{array}{l}\text { on a slope destabilised after permafrost thaw, } \\
\text { etc. (sensu Mercier 2009) }\end{array}$ & $\begin{array}{l}\text { (\#103,303 rock glacier } \\
\text { evolution) }\end{array}$ \\
\hline
\end{tabular}

note: sequence of $v$ symbols in column 2 indicates decreasing glacial / increasing fluvial signature 


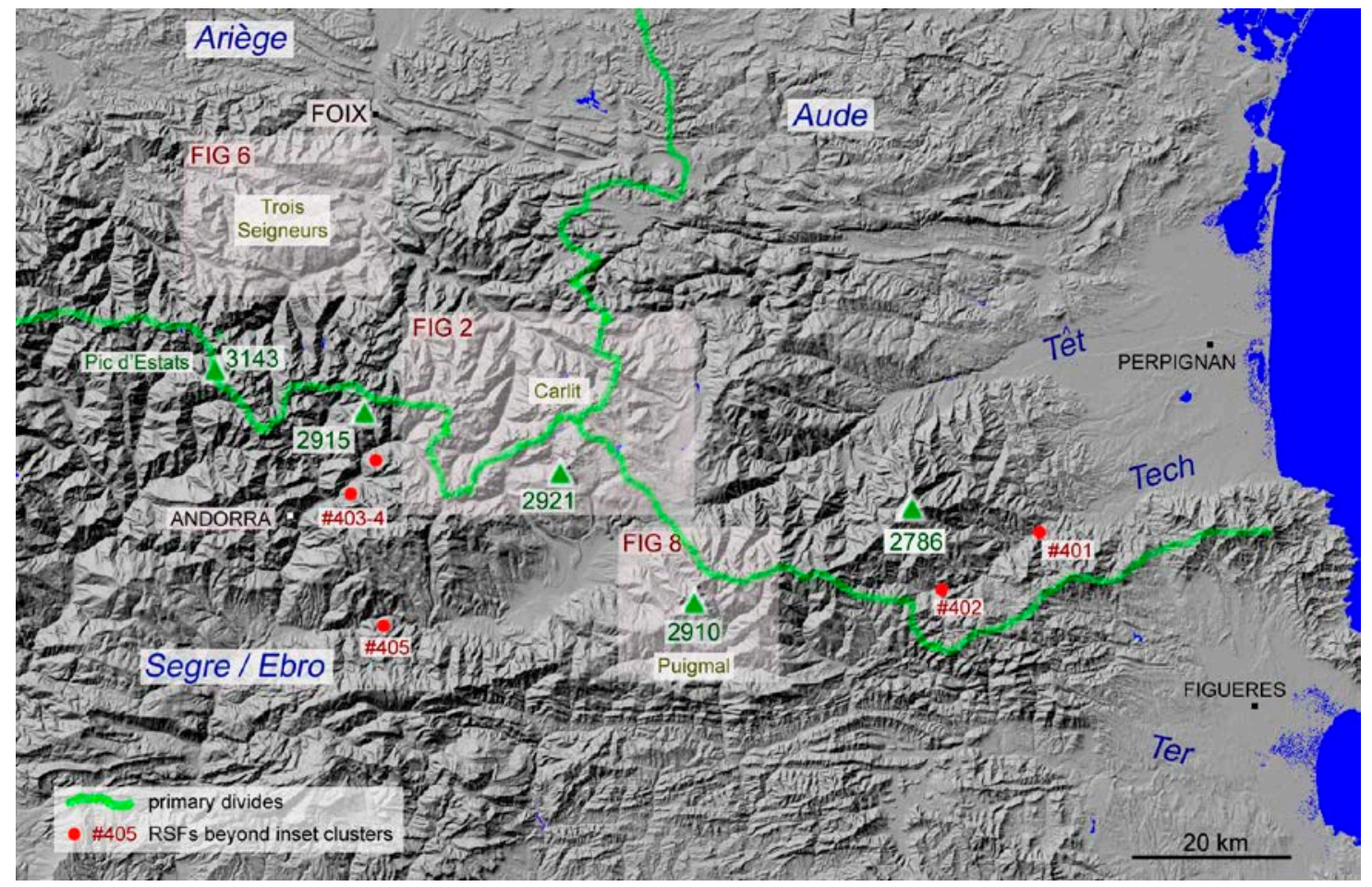

Fig. 1. The eastern Pyrenees study area. The five montane RSF groups are mapped in Figures 3/7/9/10a/11. I solated RSFs in the peripheral river valleys are shown here. All DEM extracts from Jarvis et al. (2008) 


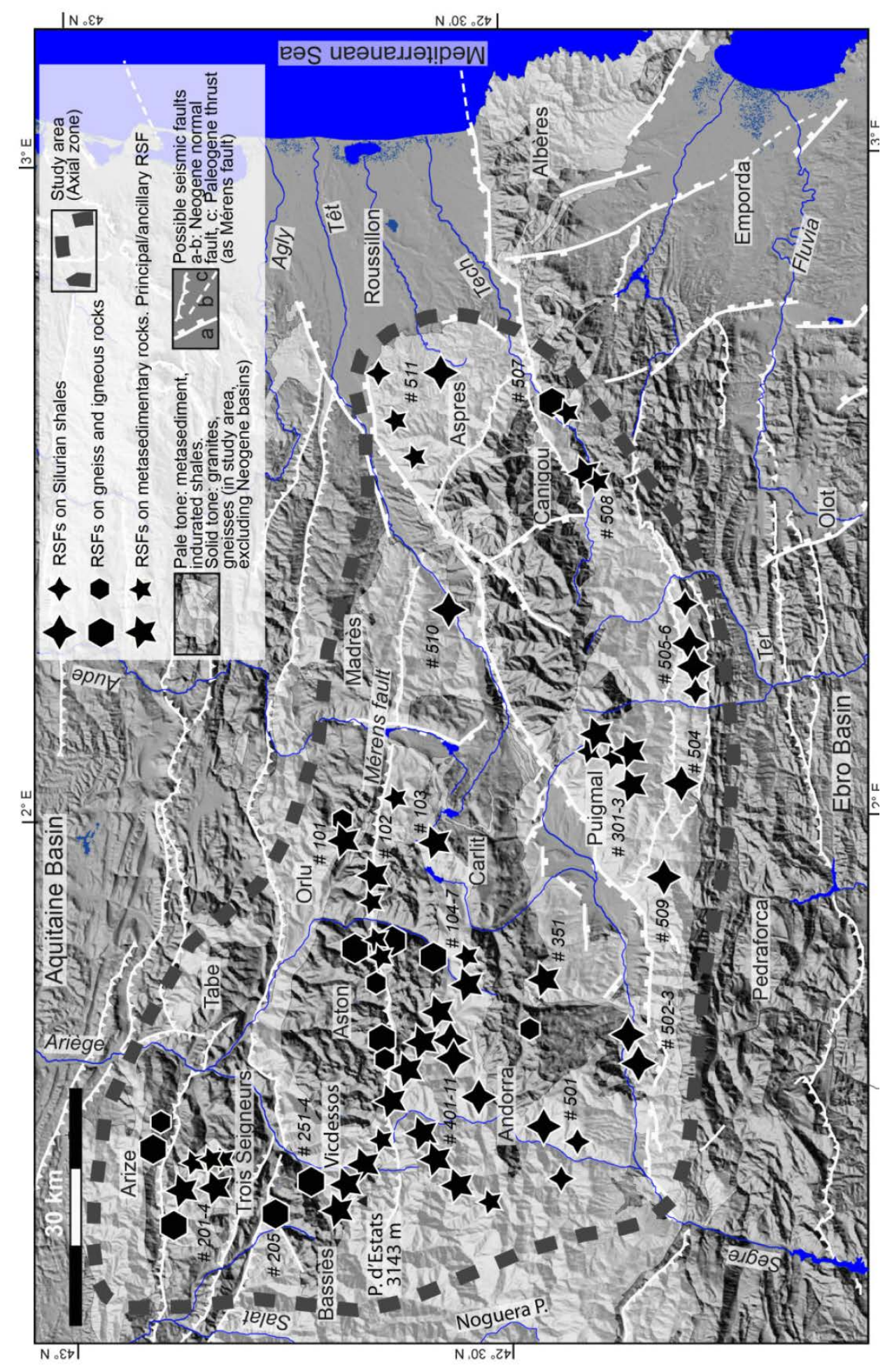

Fig. 2. The RSF population identified in the field and from imagery, to date; large symbols are principal sites characterised in Table 1, small symbols are lesser or uncertain sites. Associations with metasedimentary rocks (here including micaschist, chlorite, sericite, calcareous schist, phyllite and slate), and notably with quasi-metamorphic indurated Silurian shale outcrops, are marked but not exclusive; the overall pattern is well distributed but sparse. A series of RSFs lies close to the Mérens Fault across the centre of the area 


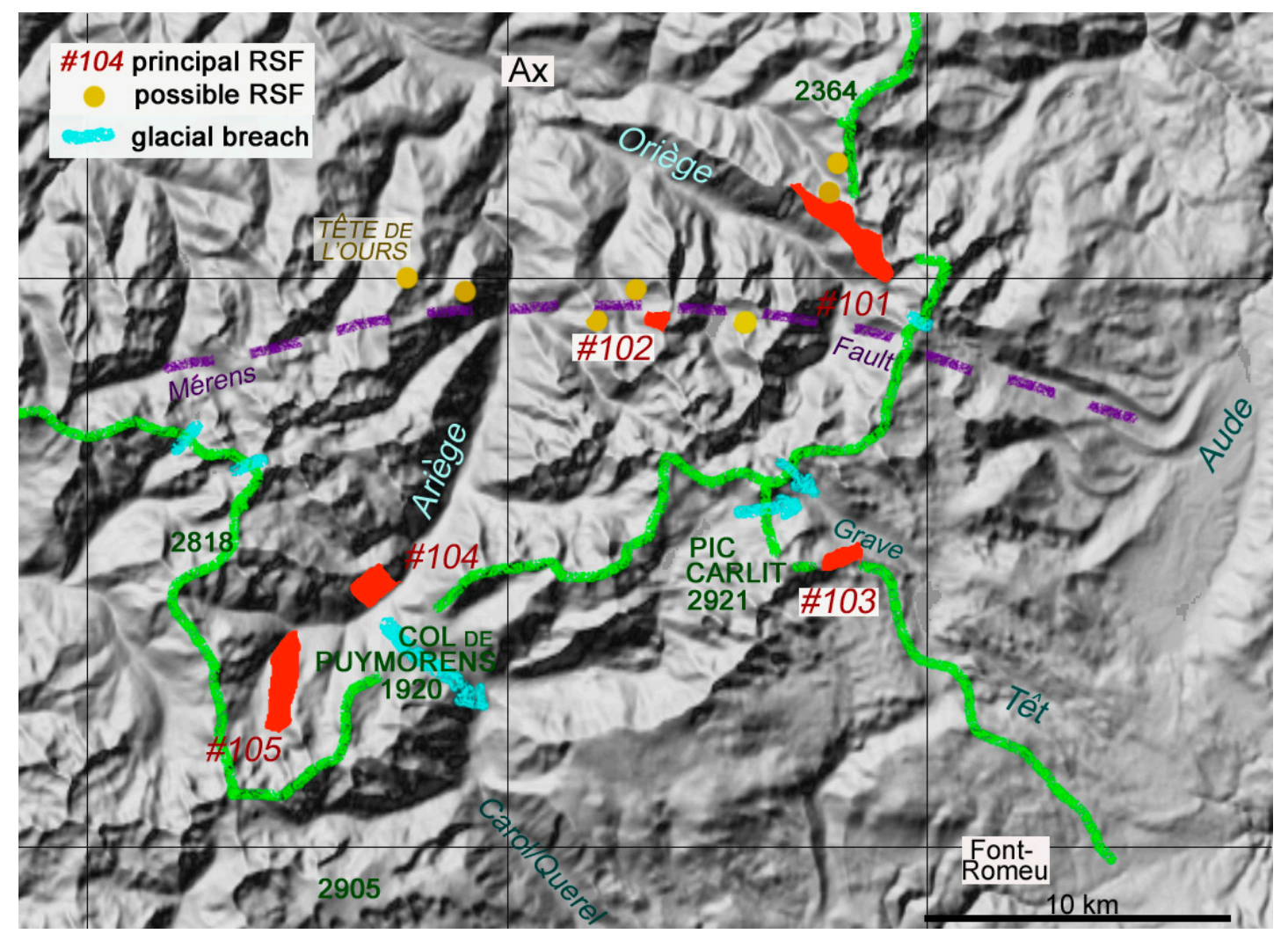

Fig. 3. Area 1 - the Carlit massif, including upper Ariège catchments of the Aston massif. All the sites (solid shapes) are in paraglacial contexts, and chiefly on metasedimentary rocks. Most are close to trough-heads. Some associate with the major Mérens Fault

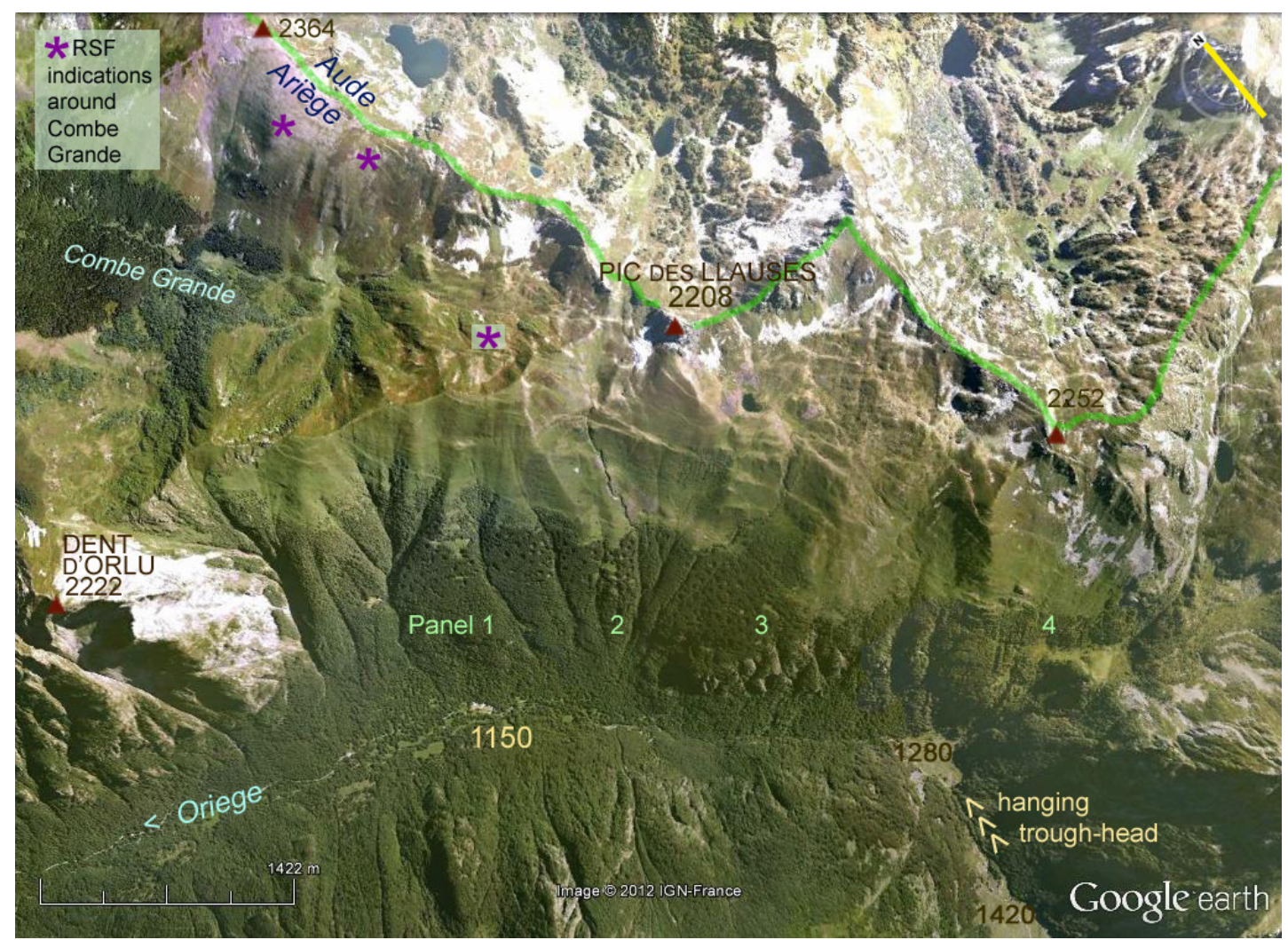




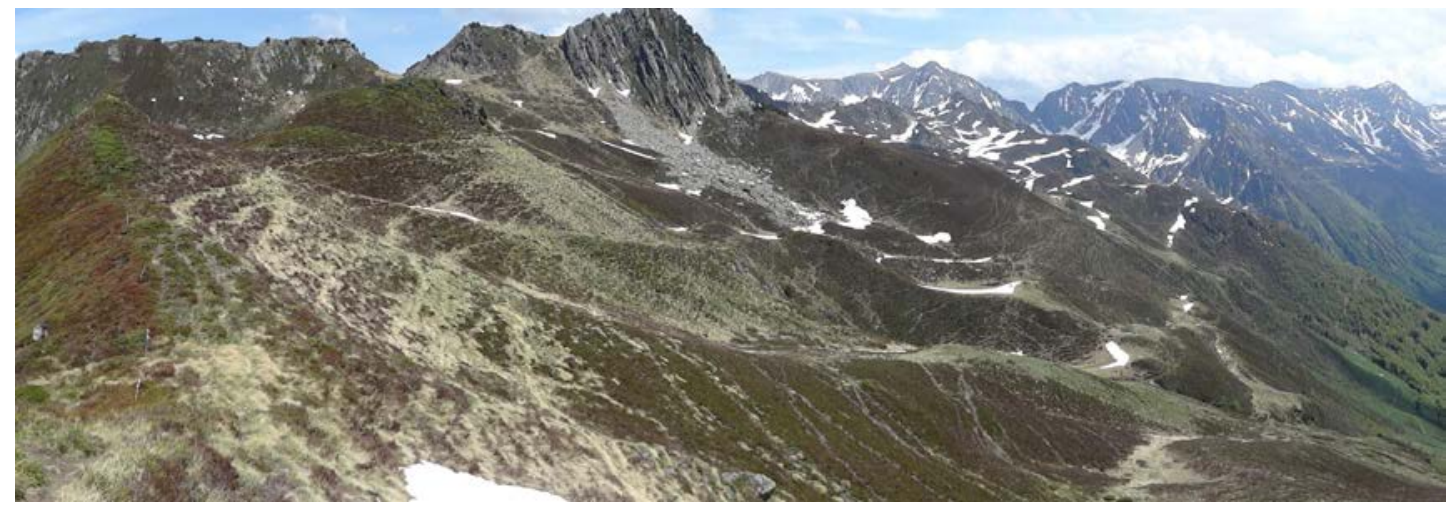

Fig. 4. RSF \#101 (Pic des Llauses, $2208 \mathrm{~m}$ ), the largest DSGSD identified in the study area. (a) Google Earth image showing deformation lineaments extending for almost $4 \mathrm{~km}$ (probable outer limits marked $x x x x$ ) above a trough over $1000 \mathrm{~m}$ deep (spot heights in metres) (b) view SE across the centre of the site, traversed by berm-antiscarps up to a kilometre long

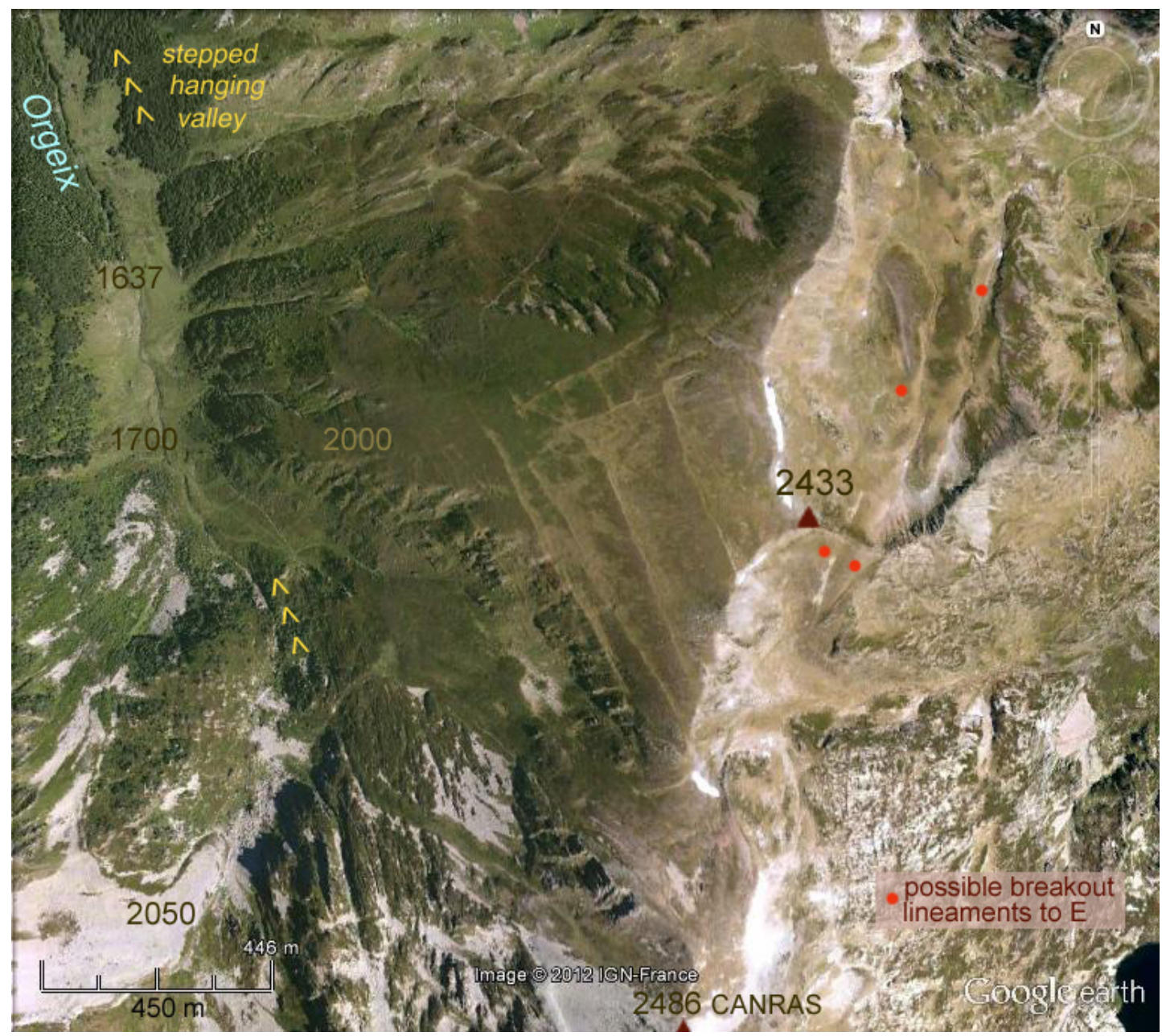




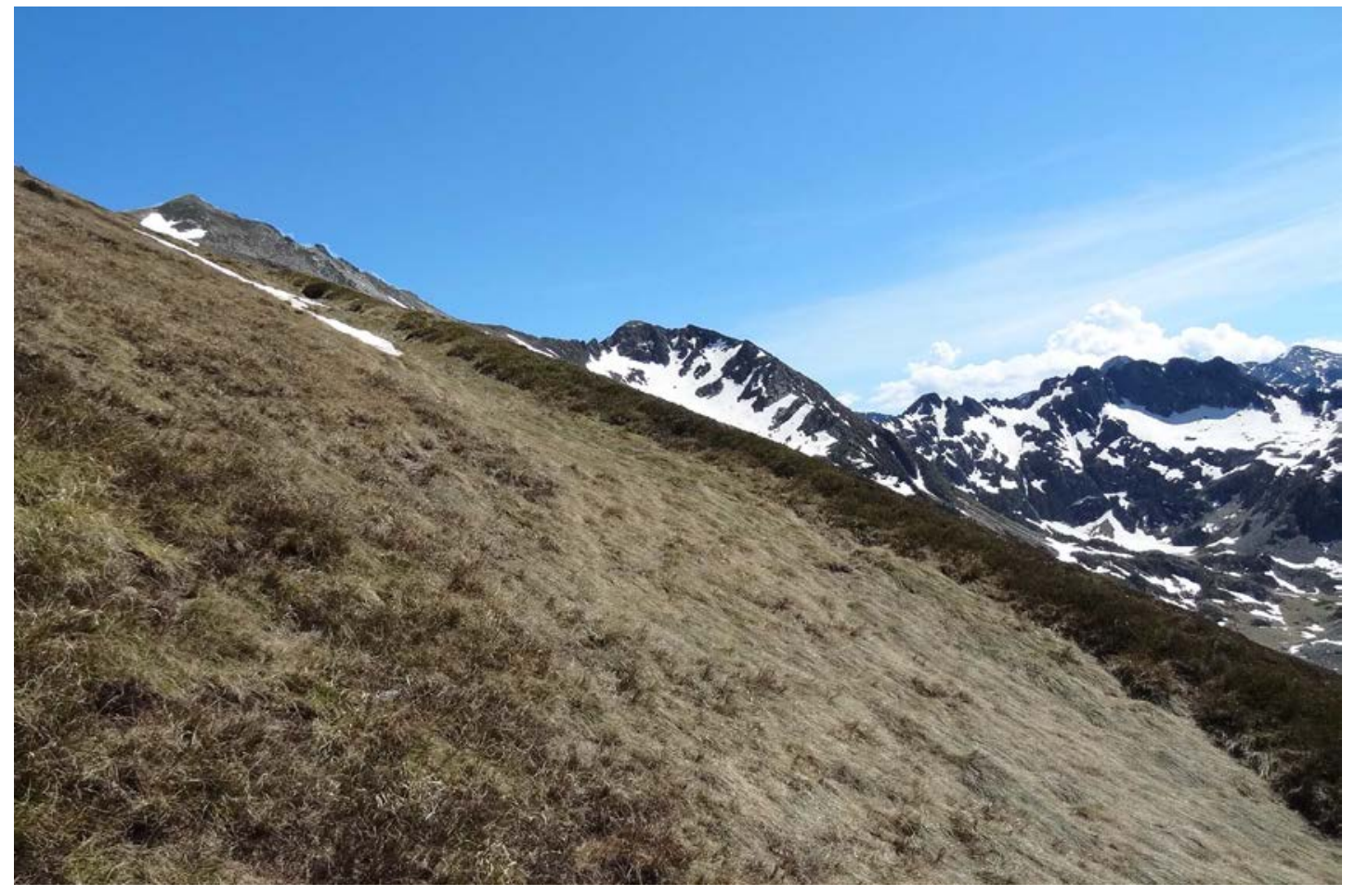

Fig. 5. RSF \#102 (Sarrat de Coste Rébenc, 2433 m), a classic in situ slope deformation of rebound character. (a) Google Earth image showing surviving fragment of paleic relief above $2000 \mathrm{~m}$, seamed with chevron antiscarps. It is undercut by a stepped glacial trough-head, and is thus clearly paraglacial (b) The second-lowest antiscarp, only $\sim 1 \mathrm{~m}$ high but sharply cut and $\sim 500 \mathrm{~m}$ long

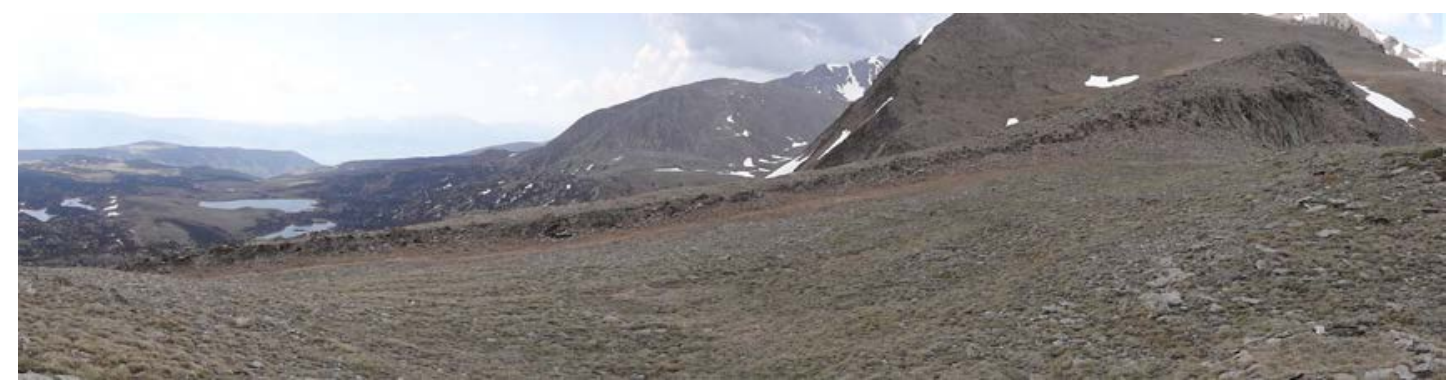




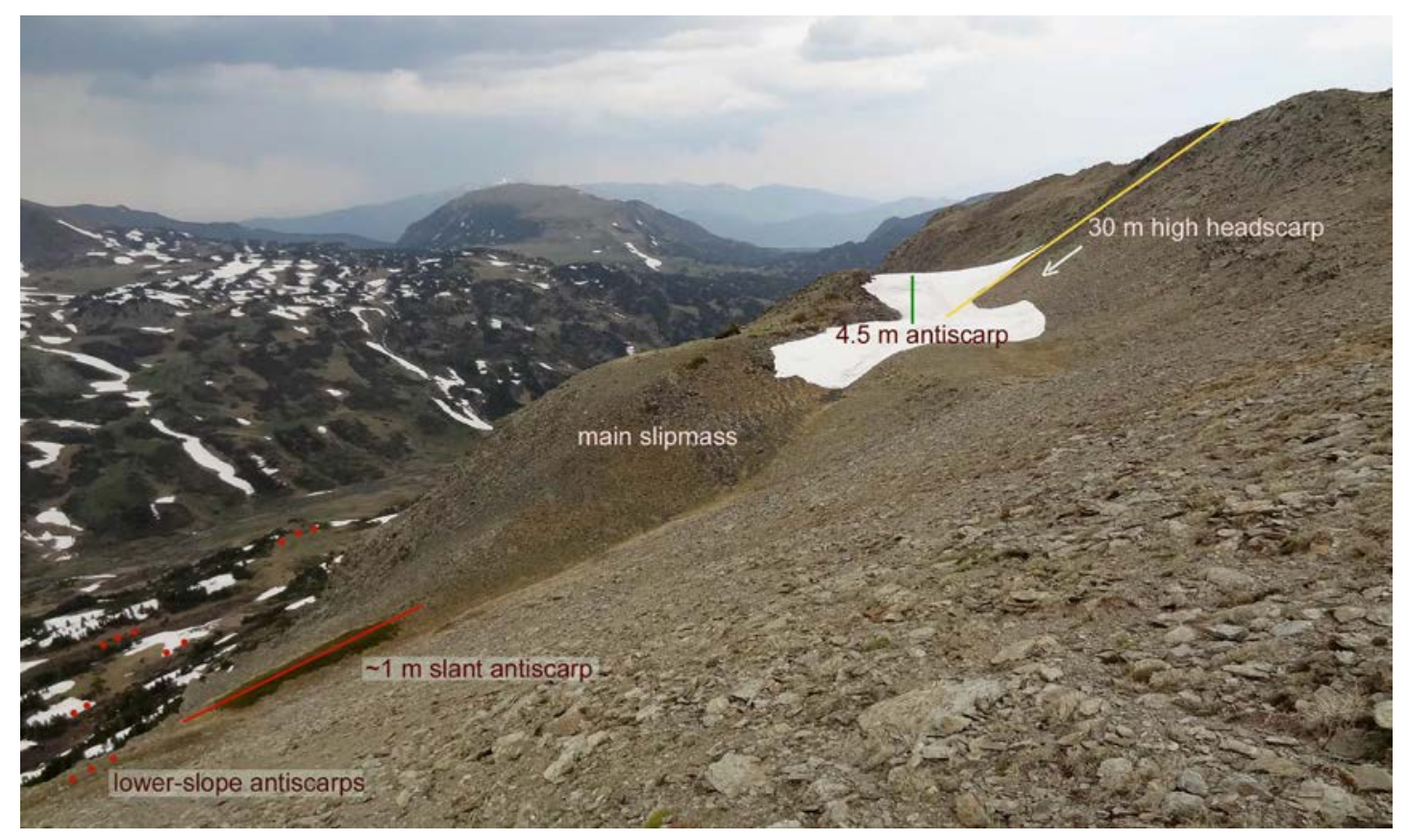

Fig. 6. RSF \#103 (Pic Carlit Castellà). (a) Google Earth oblique image showing the bold headscarp slanting across the broad ridge axis with slipmass on its north; marked viewpoints are to (b) A fresh dislocation scarplet $\sim 1 \mathrm{~m}$ high crossing the paleic-relief shoulder at an acute angle (c) The main slipmass, descended from a $30 \mathrm{~m}$ headscarp

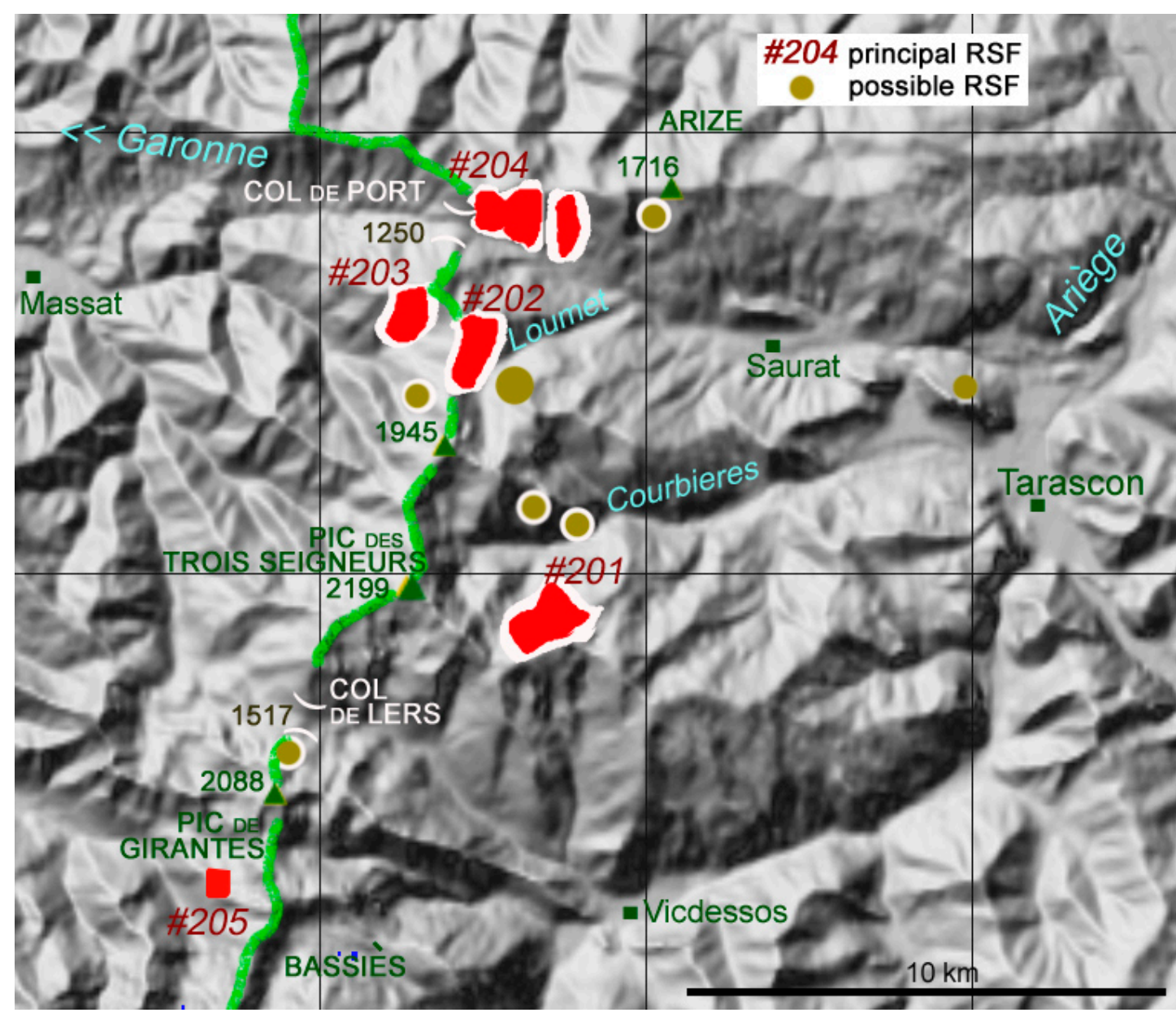


Fig. 7. Area 2A - Pic des Trois Seigneurs massif. Paraglacial RSFs occur in the Courbieres and Loumet trough-heads east of the local divide, parafluvial RSFs elsewhere, in diverse lithologies
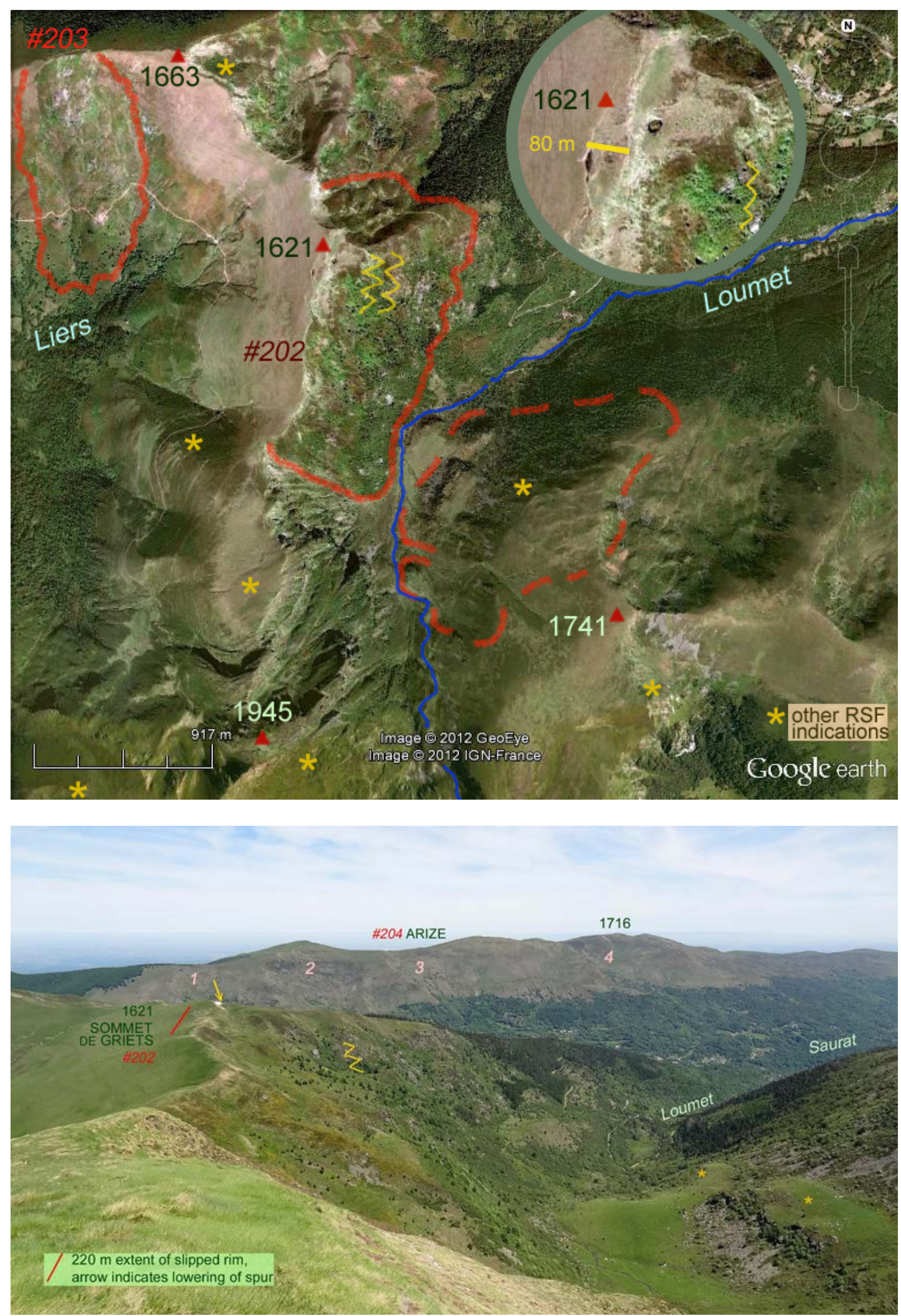
Fig. 8. RSF \#202 (Sommet des Griets, $1621 \mathrm{~m}$ asl) is at a transition from glaciated upper to more fluvial lower reaches of the Loumet valley (a) Google Earth image showing a conspicuous slice of paleic surface rim lowered by $\sim 5 \mathrm{~m}$ (see inset for detail, marking $80 \mathrm{~m}$ depth of bite along a $220 \mathrm{~m}$ front). RSF \#203 Pic d'Estibat (point 1663) is a landslip in migmatites into the entirely fluvial Massat catchment (red lines and dashes mark definite and probable RSF extents) (b) View north along the failed flank of the Loumet valley, with fissured (zigzag mark) and bulged slopes below the slipped rim; in the background, RSF \#204 (Arize) is a set of south-facing cavities and lobes in the fluvial Saurat headwater of uncertain origins (see SI-06). Extent of definite and possible RSF marked; note invasion of paleic relief, and fluvial character of outer valley

Fig. 9. Area 2B - Vicdessos massif. Google Earth image showing landslip and deformation RSFs in deep glaciated valleys close to trough heads below the range divide (\#252 is above a river gorge and thus transitional to parafluvial). All are on metasedimentary rocks, with \#251-2 close to the Bassiès granite pluton margin

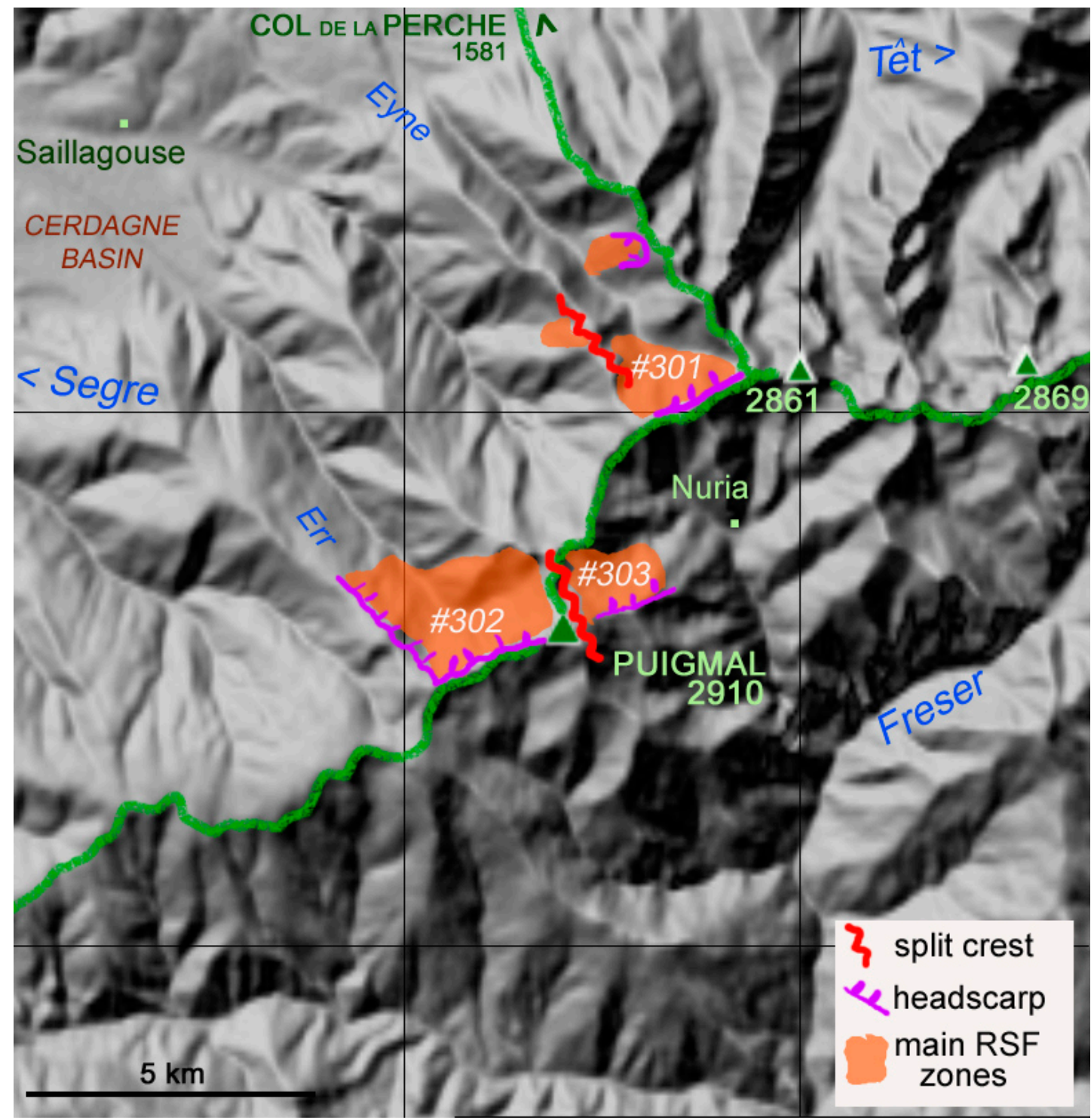



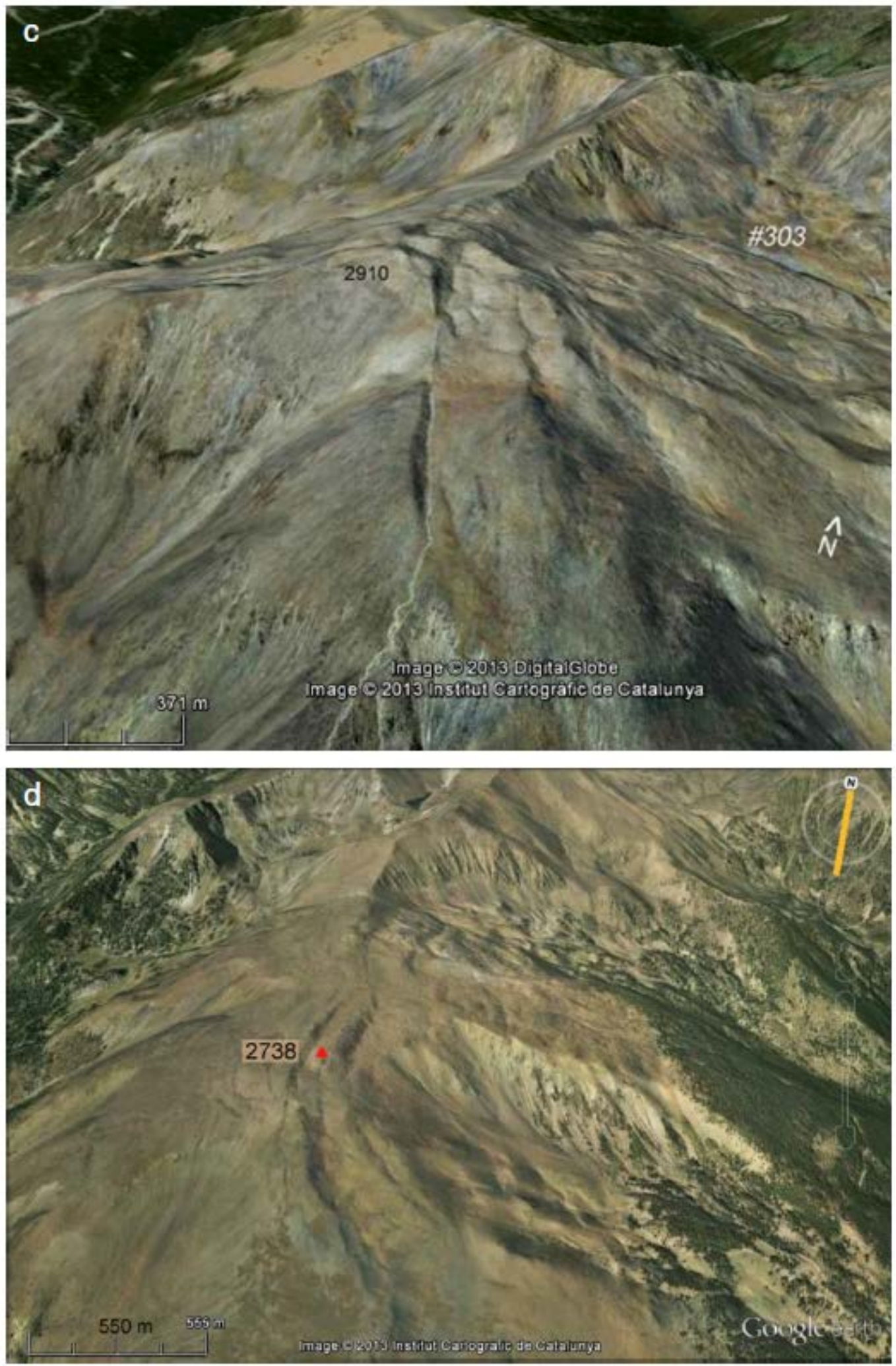

Fig. 10. The Puigmal massif RSF cluster. (a) Entire valleyheads and crestlines are disintegrating in steep fluvially-dissected relief where metasedimentary rocks and carbonates prevail. RSF is lacking in the Têt headwaters, which are in resistant gneiss conducive to cirque development (b) Oblique Google Earth image of RSF \#303 in Nuria valley head: most of the crests show splitting, with the main slipmass disintegrating to feed extensive rock glacierswith lesser slipmasses in 
the other valleyheads. The whole Err valleyhead behind (\#302) is slumping (c) Oblique Google Earth image of Puigmal south ridge split by a fracture extending north for almost a kilometer, intersecting other fractures across the summit paleic surface, and lowering a $\sim 150 \mathrm{~m}$ wide slice by $20 \mathrm{~m}$ (d) Similar behaviour on the Campcardos plateau at Serra da Coma Ermada (\#351), with multiple scarps splitting the broad summit and lowering it eastwards by 5-10 m, debris masses feeding rock glaciers in the quasi-cirques, and the entire shoulder between them apparently subsiding eastwards in slices (oblique Google Earth image, sun angle from west)

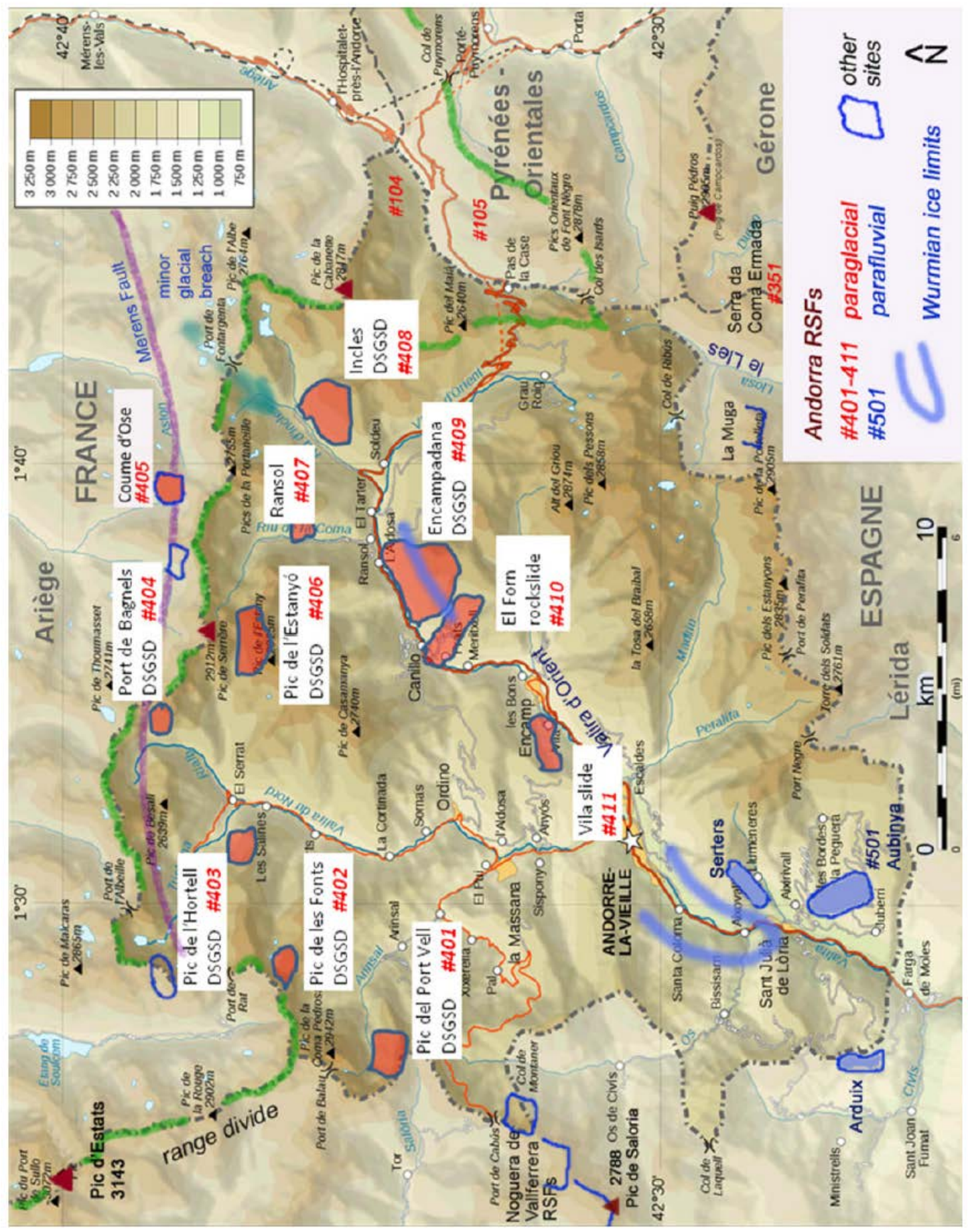

Fig. 11. The Andorra RSF cluster. A sequence of smaller but often striking RSFs in trough-head threshold locations on metasedimentary rocks is followed by several 
very large sites where weak Silurian shales dip into Valira d'Orient. Beyond the glacier limit, parafluvial RSFs occur
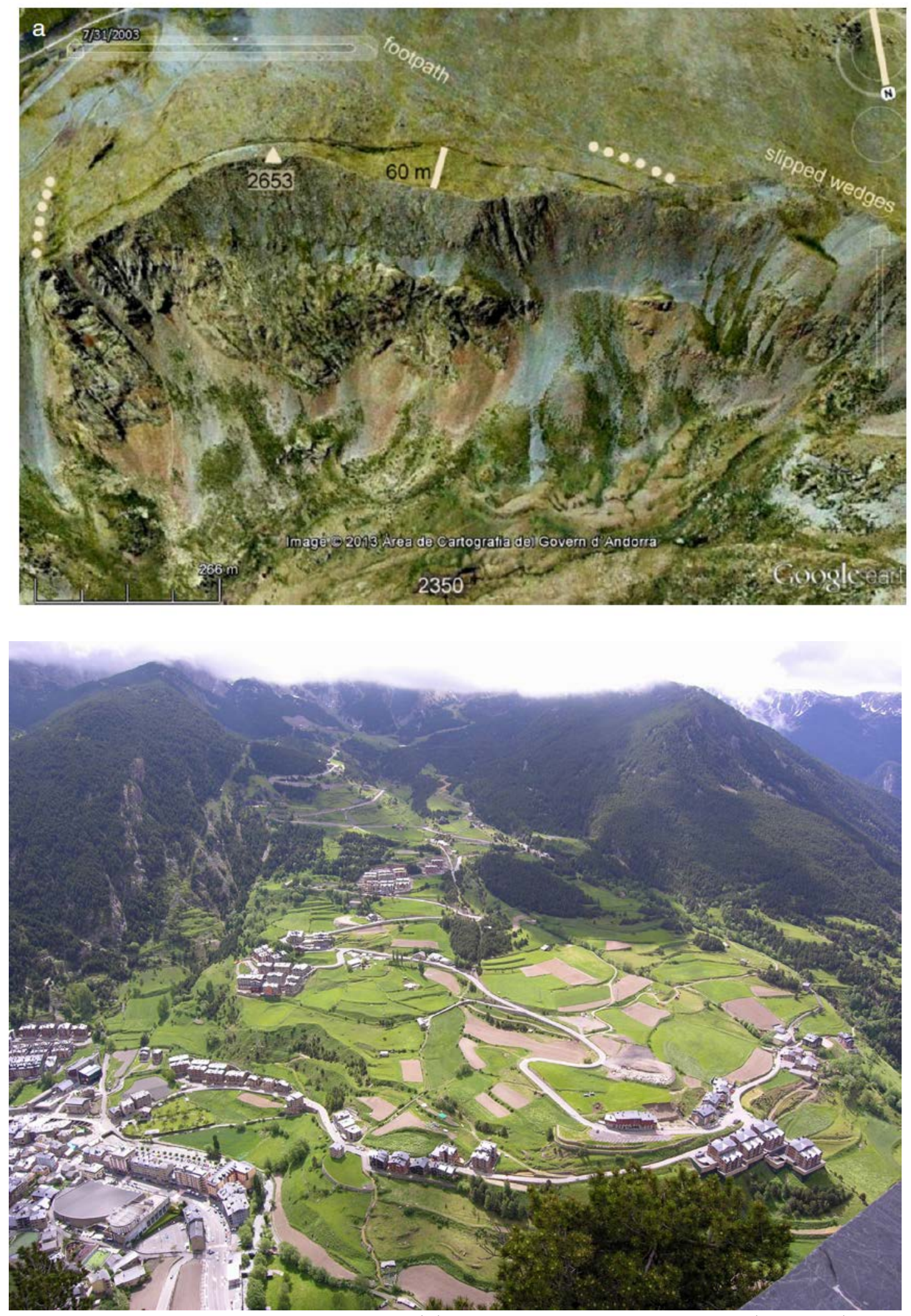

Fig. 12. Two major RSFs in Andorra. (a) Site \#401 Pic del Port Vell (2653 m) Google Earth image shows a 30-60 m wide slice of paleic surface rim prepared to fail along a $1 \mathrm{~km}$ front (between dot rows), with scars and minor slips either side; location is a side-trough flank on the Noguera-Valira divide; (b) Site \#408 (EI 
Forn) is the largest identified RSF of rockslide type in the Pyrenees, on Silurian shales below Devonian cap-rocks. Photograph looking SE from the opposite wall of the narrow glaciated Valira d'Orient valley up the landslip axis into its cavity
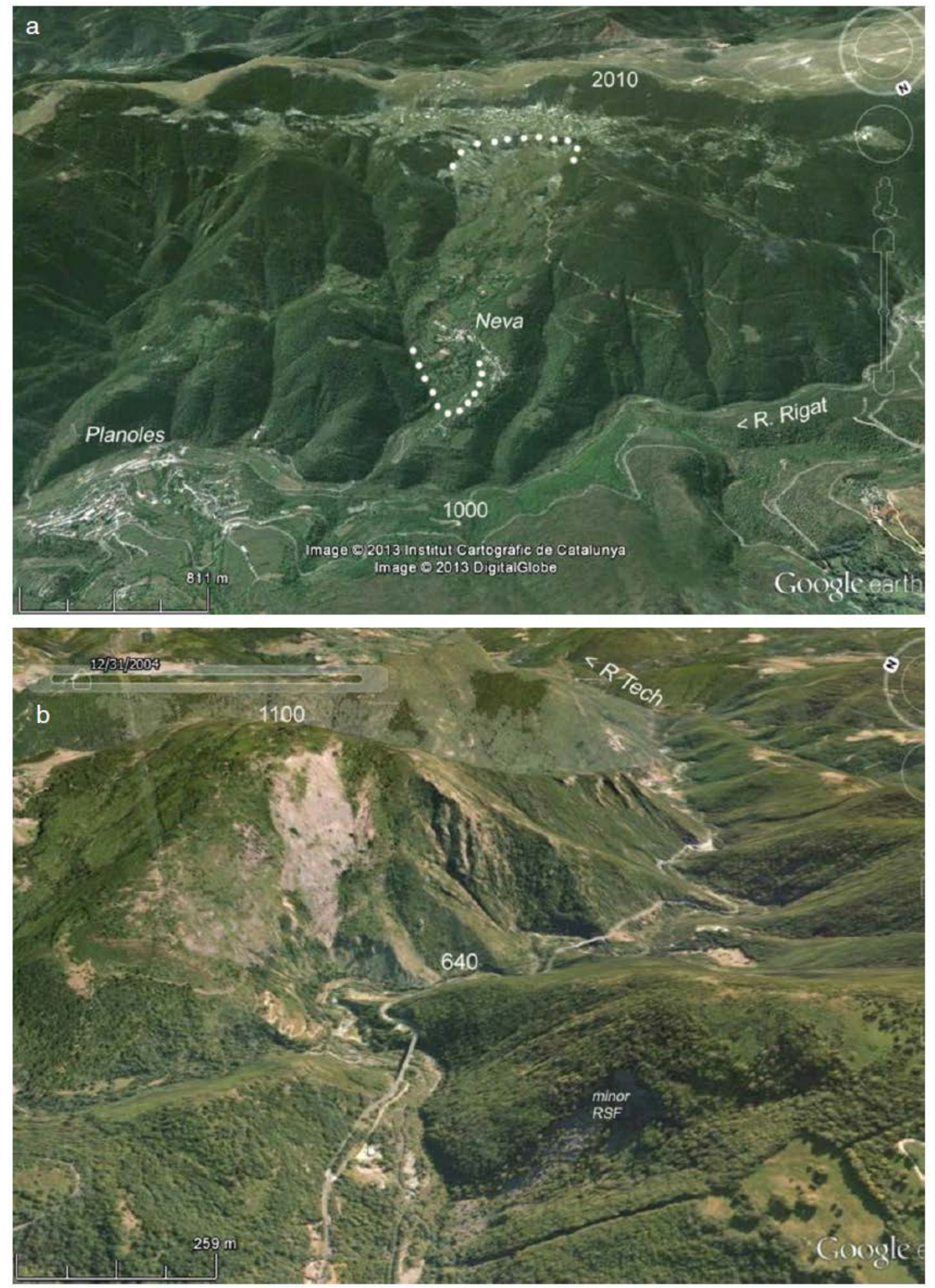

Fig. 13. Parafluvial RSFs in the major river valleys. Oblique Google Earth images show (a) Site \#504 (Nevà) stands out as free of woodland: it is a narrow landslide of earthflow type on Silurian shales dipping valleyward; its toe (dotted tongue) does not reach the river, hence it is not a directly 'fluvial RSF'; its 
immediate source (dotted) may be within a much broader long-term slump (b) The landslide at Prats de Mollo (\#508) is mainly on metasediments; although provoked by the 1940 extreme rainfall event in the Tech valley, it was not directly responding to the river undercutting the toe; it blocked the Défilé de la Baillanouse, severely damaging infrastructure, but the still-bare slipmass remains partially in its cavity; earlier scars on either side.

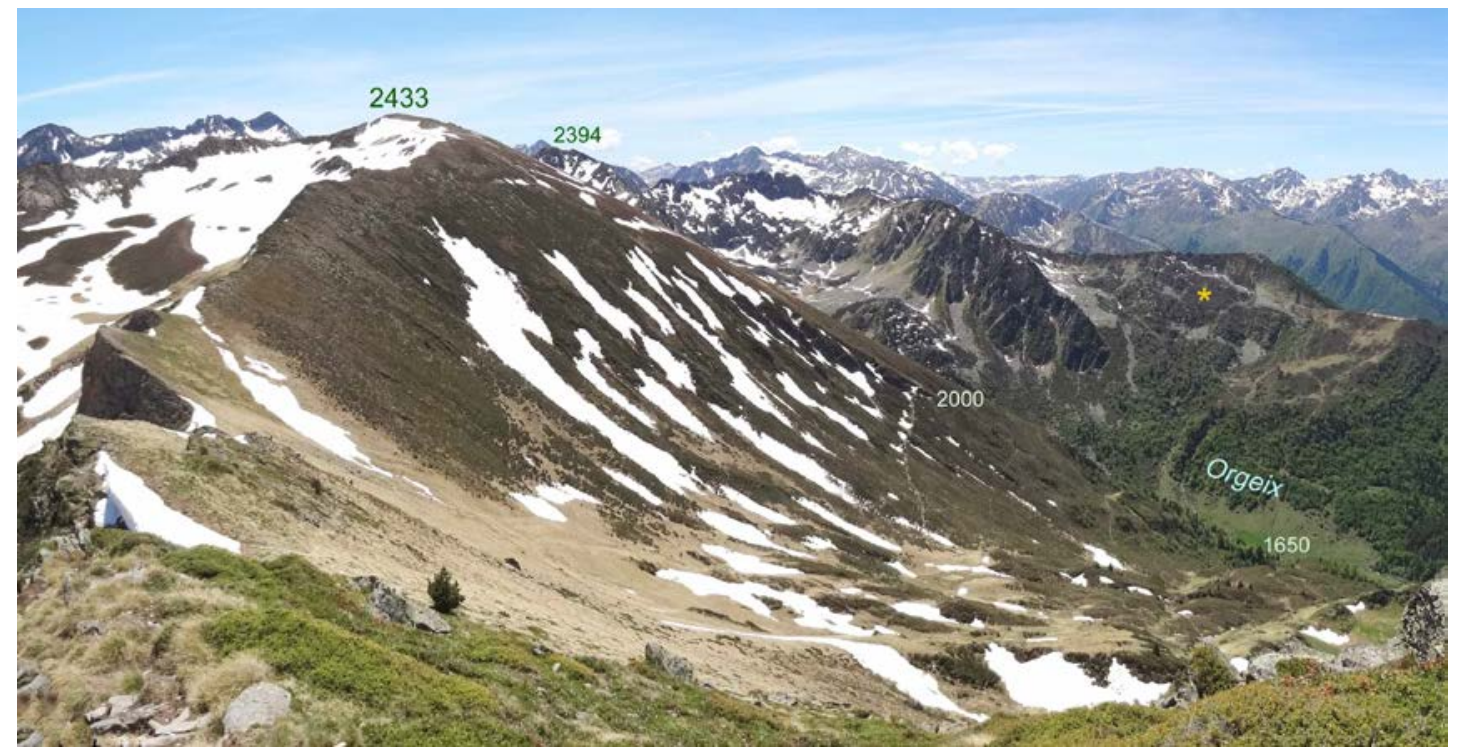

Fig. 14. RSF in a trough-head transition location and invading paleic relief, at \#102 Sarrat de Coste Rébenc. The deformation extends from its $2433 \mathrm{~m}$ summit down the smooth slope (evolved paleic surface) to the break at $2000 \mathrm{~m}$. It stands above the Saut d'Aygue Longue bedrock step from the cirque (below point 2394) into the Orgeix glacial trough. Possible matching RSF asterisked opposite (view looking SSW) 